\title{
Combination Therapy and Nanoparticulate Systems: Smart Approaches for the Effective Treatment of Breast Cancer
}

\author{
Shivaprasad Gadag ${ }^{1}$, Shristi Sinha ${ }^{1}$, Yogendra Nayak ${ }^{2} \mathbb{1}$, Sanjay Garg ${ }^{3} \mathbb{C}$ \\ and Usha Y. Nayak ${ }^{1, *(D)}$ \\ 1 Department of Pharmaceutics, Manipal College of Pharmaceutical Sciences, Manipal Academy of Higher \\ Education, Manipal 576104, India; shivaprasad.gadag@learner.manipal.edu (S.G.); \\ shristi.sinha@learner.manipal.edu (S.S.) \\ 2 Department of Pharmacology, Manipal College of Pharmaceutical Sciences, Manipal Academy of Higher \\ Education, Manipal 576104, India; yogendra.nayak@manipal.edu \\ 3 UniSA: Clinical and Health Sciences, University of South Australia, Adelaide, SA 5000, Australia; \\ sanjay.garg@unisa.edu.au \\ * Correspondence: usha.nayak@manipal.edu
}

Received: 19 May 2020; Accepted: 4 June 2020; Published: 8 June 2020

\begin{abstract}
Breast cancer has become one of the biggest concerns for oncologists in the past few decades because of its unpredictable etiopathology and nonavailability of personalized translational medicine. The number of women getting affected by breast cancer has increased dramatically, owing to lifestyle and environmental changes. Besides, the development of multidrug resistance has become a challenge in the therapeutic management of breast cancer. Studies reveal that the use of monotherapy is not effective in the management of breast cancer due to high toxicity and the development of resistance. Combination therapies, such as radiation therapy with adjuvant therapy, endocrine therapy with chemotherapy, and targeted therapy with immunotherapy, are found to be effective. Thus, multimodal and combination treatments, along with nanomedicine, have emerged as a promising strategy with minimum side effects and drug resistance. In this review, we emphasize the multimodal approaches and recent advancements in breast cancer treatment modalities, giving importance to the current data on clinical trials. The novel treatment approach by targeted therapy, according to type, such as luminal, HER2 positive, and triple-negative breast cancer, are discussed. Further, passive and active targeting technologies, including nanoparticles, bioconjugate systems, stimuli-responsive, and nucleic acid delivery systems, including siRNA and aptamer, are explained. The recent research exploring the role of nanomedicine in combination therapy and the possible use of artificial intelligence in breast cancer therapy is also discussed herein. The complexity and dynamism of disease changes require the constant upgrading of knowledge, and innovation is essential for future drug development for treating breast cancer.
\end{abstract}

Keywords: combination therapy; PI3K/AKT/mTOR inhibitors; monoclonal antibodies; immunotherapy; antibody-drug conjugates; nanomedicine

\section{Introduction}

Breast cancer $(\mathrm{BC})$ is one of the most common cancers prevalent across the globe and is one of the leading causes of mortality and morbidity in women [1]. The incidence of $\mathrm{BC}$ cases is expected to increase mainly due to aging and population growth. It is expected that by 2030 , the incidence rate increase by $50 \%$ [2]. The challenges met during treatment are very vivid because of the heterogeneous property of disease [3]. The reason behind the prevalence of the disease is the substantial individual 
variation. The incidence of breast cancer are on the rise due to a change in lifestyle and availability of modern screening techniques. Despite the advances in screening techniques, mortality rates are higher, especially in developing countries, due to a lack of easy access to state-of-the-art diagnosis and treatment facilities. In addition, a speedy cancer progression and metastasis can be the reasons for the reduced survival rate.

BC is classified based on features, namely, histopathology, molecular subtypes, stage of cancer, grade, and based on DNA alteration. The treatment point of view classification based on molecular subtypes is the most accepted. Molecular subtyping of breast cancer explains its four types of nature, namely, luminal breast cancer (LBC) type A, LBC type B, human epidermal growth factor receptor 2 (HER2) positive breast cancer, and triple-negative breast cancer (TNBC) [4]. The LBC is further subdivided into type-A and type-B, which differ in their etiology. Type-A shows a positive test only for hormone receptors (HR), which includes both progesterone and estrogen receptors. In the case of type-B, both HR and HER tests are positive. In addition to these two types, BC also shows a high amount of Ki-67 expression. LBC type-A progresses slowly and can be treated in its early stages. In contrast, type-B is highly progressive, and its early-stage detection is not usually possible, making it more fatal [5]. The third molecular subtype, HER2-positive cancer, has a predominant expression of HER2/ERBB2 oncogene. TNBC, the fourth molecular subtype, lacks both HR and HER2 and is considered to be the most aggressive form of BC. TNBC can further classified into six subclasses, namely, luminal androgen receptor subtype, immunomodulator, mesenchymal, stem-like mesenchymal, and basal-like (BL1 and BL2). According to cancer statistics, $84 \%$ of BCs are HR-positive cancers. Among the HR-positive diseases, $71 \%$ are affected by type-A LBC, and the rest, $12 \%$, are affected by type-B LBC. Around 5\% of the cancer patients are affected by HER2-positive and HR-negative, and the remaining $12 \%$ suffer from TNBC [6].

Based on various factors such as cancer stage, presence/absence of hormone receptors, genetic and epigenetic alterations, and biomarkers, different treatment strategies are adopted. Such strategies include surgery, chemotherapy, radiation therapy, hormone therapy, immunotherapy, targeted therapy used alone or in combination. An exhaustive set of literature is available on the treatment options for BC. In the first part of the present review, we discuss the current multimodal treatment options, including combination therapy for BC, followed by the newer strategies adopted. The lists of drugs that are under clinical development are detailed according to their clinical applicability. The recent research related to the utilization of nanotechnological platforms to deliver drugs effectively is included in the second part of this review.

\section{Treatment Strategies for Breast Cancer}

\subsection{Current Treatment Approaches}

\subsubsection{Therapeutic Options for Luminal Breast Cancer}

Approximately $60 \%$ to $80 \%$ of premenopausal women with BC belong to the HR-positive type $[5,6]$. If breast cancer has a significant number of hormone receptors for estrogen or progesterone, it is classified as HR-positive. The growth of the tumor is fueled by estrogen and progesterone in HR-positive BC. The best-suited therapy for HR-positive BC is by targeting the estrogen receptors, and these hormone levels can either be reduced or blocked. The estrogen receptor (ER) blockers, such as tamoxifen, prevent the attachment of estrogen, arresting the BC growth [7]. Fulvestrant is another drug that belongs to the class of estrogen-degrading agents, which selectively destroy the estrogen receptors [8]. Another mechanism is by targeting the aromatase enzyme, which is responsible for the conversion of androgen to estrogen. The agents approved for this action are exemestane, anastrozole, and letrozole. Further, leuprolide and goserelin the potent gonadotropin-releasing hormone receptor (GnRHR) agonists have been approved, which inhibit hormone production from the ovary. However, the major limitation of endocrine therapy is the development of resistance, which causes the relapse of BC and poor clinical outcomes $[9,10]$. 


\subsubsection{Treatment Options for HER2-Positive BC}

For the treatment of HER2-positive BC in its early stage, combinational therapy is the preferred treatment of choice, e.g., palbociclib in combination with hormone therapy (such as fulvestrant, an anti-estrogen drug, or letrozole, an aromatase inhibitor). However, the above treatment regimen is not enough for the complete removal of cancer cells. Following combinational therapy, surgery is performed, followed by radiotherapy and a year of continuous anti-HER2 targeted treatment. There are different drugs available for the treatment, namely, lapatinib, a tyrosine kinase receptor inhibitor that interrupts both HER2 and epidermal growth factor receptor (EGFR), and microtubule inhibitors linked with antibody cytotoxic agents, e.g., emtansine linked with the monoclonal antibody trastuzumab [4].

\subsubsection{Management of Triple-Negative Breast Cancer (TNBC)}

TNBC is clinically and histopathologically different from the rest of $B C$, and it requires different treatment approaches. TNBC has the highest rates of recurrence, which makes it the most challenging type of $\mathrm{BC}$ to be treated [11]. Chemotherapy using taxanes, anthracycline, and platinum drugs remains the standard treatment for TNBC.. This conventional treatment can be combined with anti-VEGF monoclonal antibody bevacizumab. The vascular endothelial growth factor (VEGF) is oncogenic and can be a druggable target in BC [12]. Since TNBC lacks all the receptors, the use of targeted therapy to the receptor does not work. Thus, there is an inevitable need for newer, aggressive targeted technology for the better treatment of TNBC [4].

\subsection{Novel Treatment Approaches for Breast Cancer by Targeted Therapy}

As the name indicates, targeted therapy refers to targeting specific biological macromolecules or biochemical pathways in cancer cell metabolism. Generally, there are two types of targeted therapy used: one is the small molecular targeted therapy, and the other is the use of monoclonal antibodies. The commonly used agents under targeted therapy for breast cancer are presented in Figure 1 and discussed in this section, according to the types of BC.

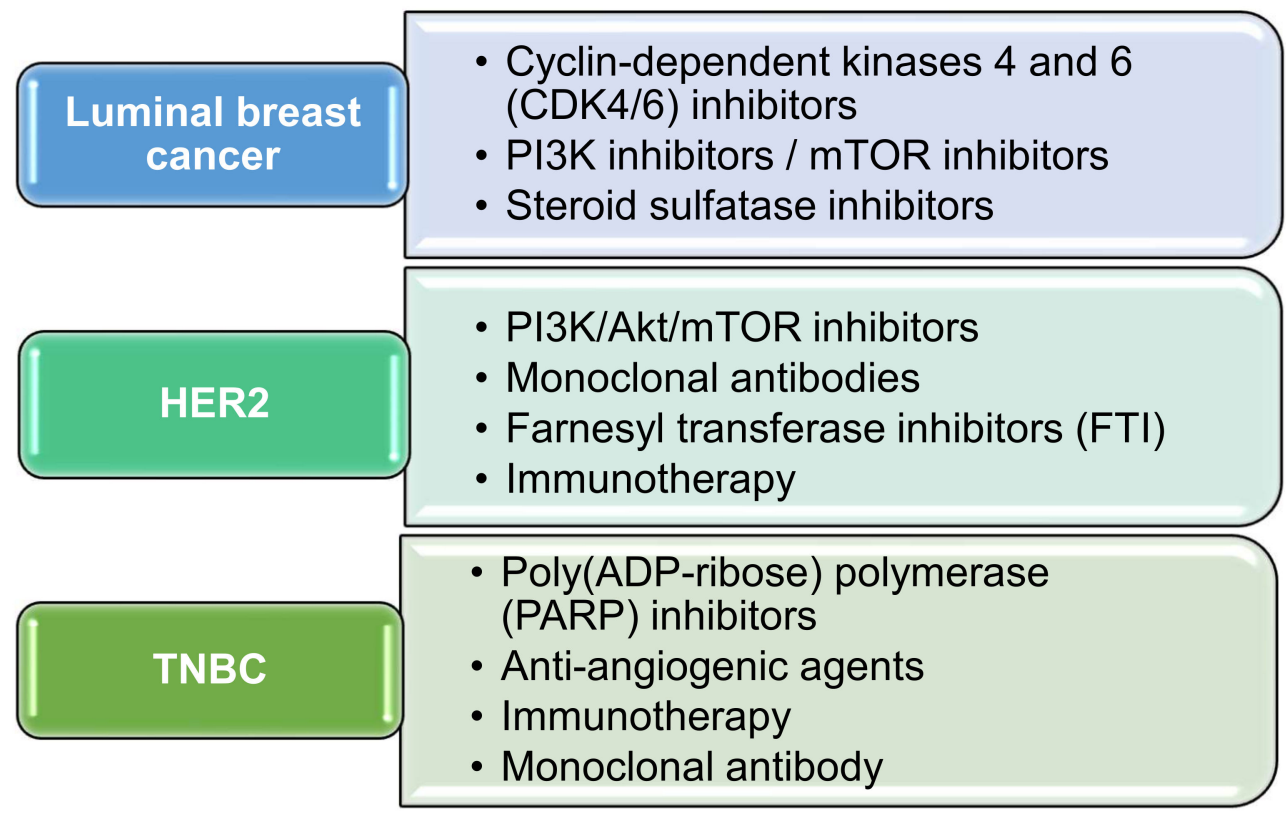

Figure 1. Classification of drugs under targeted therapy based on the type of breast cancer. 


\subsubsection{Therapy of Luminal Breast Cancer (LBC)}

\section{CDK4/6 Inhibitors}

Cyclin-dependent kinase 4 and 6 (CDK4/6) inhibitors have become one of the prime targets for inhibiting cancer growth. It interacts reversibly with cyclin D1 and regulates cell cycle progression. When the tumor develops hormone resistance, they still depend on the proliferation of CDK4/6-cyclin D1 [13]. The first mechanism by which these inhibitors work is by the blocking of retinoblastoma ( $R b)$ protein, which helps in the phosphorylation of kinases (Figure 2). The phosphorylation process leads to G1-S cell cycle arrest, which is very prominent in the treatment of BC as a combinational therapy, including CDK4/6 inhibitors and hormonal treatment. CDK4/6 also works by dephosphorylating Forkhead box protein M1, which further inhibits cell proliferation [14]. In phase III studies on metastatic breast cancer, the highly selective oral CDK4/6 inhibitors were examined in combination with endocrine therapy. The CDK4 (INK4)-Rb CDK4/6-inhibitor plays a vital role in the progression of the cell cycle, and its dysregulation is a significant contributor to the resistance of endocrine therapy. Palbociclib, ribociclib, and abemaciclib are the drugs that have been approved for the treatment of BC, which have shown a higher affinity and potency towards CDK4, as compared to CDK6 (Table 1) [15]. Clinical trials of these drugs revealed that the oral dosage showed a low and easily manageable toxicity [16]. Neutropenia and thrombocytopenia were the significant side effects in palbociclib- and ribociclib-treated patients while abemaciclib presented neutropenia, diarrhea, and fatigue as the major side effects. US FDA has approved ribociclib, abemaciclib, and palbociclib for HR-positive, HER2-negative, and metastatic BC (MBC) in July 2018, February 2018, and March 2017, respectively [17-19].

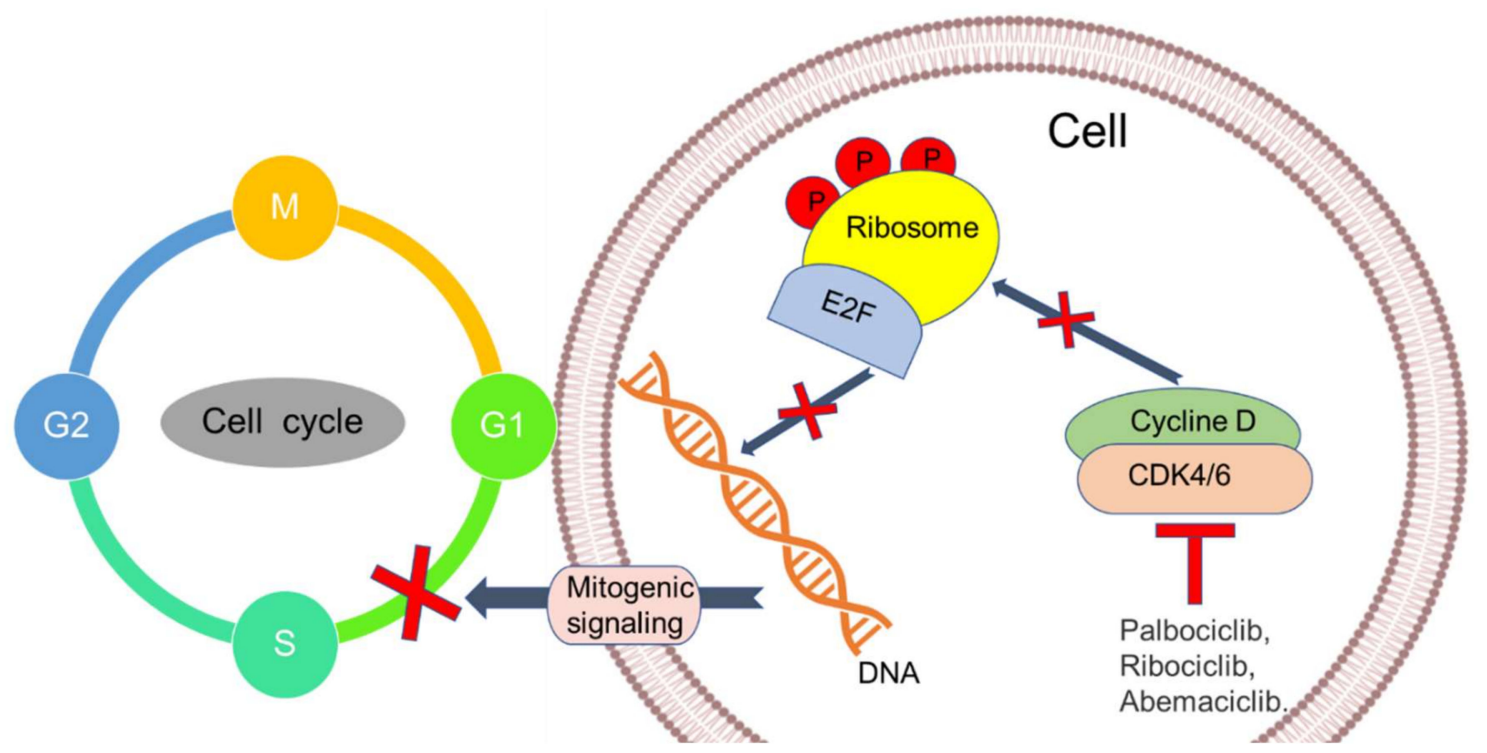

Figure 2. Schematic representation of the mechanism of CDK4/6 inhibitors. E2F-a group of genes that encodes a family of transcription factors, CDK4/6 — cyclin-dependent kinase 4/6, DNA—deoxyribonucleic acid.

Table 1. The potency of cyclin-dependent kinase (CDK)-inhibitors [15].

\begin{tabular}{ccc}
\hline \multirow{2}{*}{ Agent } & \multicolumn{2}{c}{ Cyclin-Dependent Kinase IC $_{50}$ (in nM) } \\
\cline { 2 - 3 } & CDK6 & CDK4 \\
\hline Ribociclib & 39 & 10 \\
\hline Palbociclib & 15 & 11 \\
\hline Abemaciclib & 9.9 & 2 \\
\hline
\end{tabular}


Combination therapy is a well-known option to reduce side effects and enhance therapeutic outcomes. Table 2 presents the clinical trials that are ongoing to ascertain the efficacy of combination therapy given along with CDK4/6 inhibitors.

Table 2. CDK4/6 inhibitors with other chemotherapeutic agents in clinical trials as combination therapy.

\begin{tabular}{|c|c|c|c|c|}
\hline Drug & Combination With & Description & $\begin{array}{l}\text { ClinicalTrials.Gov } \\
\text { Identifier NCT Number }\end{array}$ & Phase \\
\hline Palbociclib & $\begin{array}{l}\text { Endocrine therapy (exemestane, } \\
\text { fulvestrant, letrozole, tamoxifen) } \\
\text { Chemotherapy (capecitabine, } \\
\text { epirubicin, paclitaxel, vinorelbine) }\end{array}$ & $\begin{array}{l}\text { To evaluate/compare palbociclib in } \\
\text { combination with endocrine } \\
\text { therapeutic agents and with } \\
\text { chemotherapeutic agents in } \\
\text { HER2-positive or HER2-negative } \\
\text { metastatic BC patients }\end{array}$ & NCT03355157 & IV \\
\hline Palbociclib & $\begin{array}{l}\text { Fulvestrant, exemestane, letrozole, } \\
\text { anastrozole }\end{array}$ & $\begin{array}{l}\text { To evaluate eHealth-support in locally } \\
\text { advanced or metastatic BC patient's } \\
\text { life quality when treated with } \\
\text { palbociclib with endocrine therapy }\end{array}$ & NCT03220178 & IV \\
\hline Ribociclib & Endocrine therapy & $\begin{array}{l}\text { To study the effectiveness of ribociclib } \\
\text { with endocrine therapy in } \\
\text { the ER-positive BC patients }\end{array}$ & NCT03285412 & II \\
\hline Ribociclib & Letrozole/anastrozole, goserelin & $\begin{array}{l}\text { To evaluate the safety and efficacy of } \\
400 \mathrm{mg} \text { of ribociclib when given in } \\
\text { combination with aromatase } \\
\text { inhibitors in the post- } \\
\text { and pre-menopausal women with } \\
\text { HR-positive/HR-negative patients } \\
\text { with advanced BC }\end{array}$ & NCT03822468 & II \\
\hline Ribociclib & $\begin{array}{l}\text { Letrozole } 2.5 \mathrm{mg} \text {, doxorubicin, } \\
\text { cyclophosphamide, paclitaxel }\end{array}$ & $\begin{array}{l}\text { To evaluate the efficacy and safety of } \\
\text { ribociclib (LEE011) with multi-agent } \\
\text { chemotherapy or letrozole in } \\
\text { postmenopausal patients with } \\
\text { luminal B/HER2 negative BC }\end{array}$ & NCT03248427 & II \\
\hline Ribociclib & $\begin{array}{l}\text { Non-steroidal aromatase inhibitors- } \\
\text { letrozole } 2.5 \mathrm{mg} / \text { day or anastrozole } \\
1 \mathrm{mg} / \text { day orally, } \\
\text { LHRH agonist-triptorelin } 3.75 \mathrm{mg} \text { or } \\
\text { leuprolide } 3.75 \mathrm{mg} \text { or goserelin } \\
\quad 3.6 \mathrm{mg} \text {, as injectable }\end{array}$ & $\begin{array}{l}\text { Ribociclib in combination with a } \\
\text { non-steroidal aromatase } \\
\text { inhibitor/LHRH agonist in } \\
\text { HR-Positive/HER2-negative patients } \\
\text { with advanced BC }\end{array}$ & NCT03944434 & II \\
\hline Ribociclib & PDR001, fulvestrant & $\begin{array}{c}\text { Ribociclib (LEE011), in combination } \\
\text { with PDR001 an immunotherapeutic } \\
\text { drug and fulvestrant in HR-positive, } \\
\text { HER2-negative patient for metastatic } \\
\text { hormone-receptor-positive (HR+), } \\
\text { HER2-negative BC. }\end{array}$ & NCT03294694 & I \\
\hline Ribociclib (LEE011) & Paclitaxel & $\begin{array}{l}\text { To assess the safety and dose } \\
\text { escalation of paclitaxel with ribociclib } \\
\text { in retinoblastoma }(\mathrm{Rb}) \text {-positive } \\
\text { patients with advanced BC. }\end{array}$ & NCT02599363 & I \\
\hline Abemaciclib & Fulvestrant & $\begin{array}{l}\text { To compare the effectiveness of } \\
\text { combination therapy of abemaciclib } \\
\text { with fulvestrant and chemotherapy in } \\
\text { HR-positive, HER2-negative patients } \\
\text { with metastatic BC (visceral } \\
\text { Metastases) }\end{array}$ & NCT04031885 & IV \\
\hline Abemaciclib & Fulvestrant & $\begin{array}{l}\text { To compare fulvestrant alone with a } \\
\text { combination of fulvestrant } \\
\text { and abemaciclib in progression-free } \\
\text { survival in HR-positive } \\
\text { and HER2-negative patients. }\end{array}$ & NCT02107703 & III \\
\hline Abemaciclib & $\begin{array}{l}\text { Atezolizumab (MPDL3280A), } \\
\text { bevacizumab, entinostat, exemestane, } \\
\text { fulvestrant, ipatasertib, tamoxifen }\end{array}$ & $\begin{array}{l}\text { To evaluate the safety, efficacy, } \\
\text { and pharmacokinetics of } \\
\text { immunotherapy-based combination } \\
\text { with CDK } 4 / 6 \text { inhibitor } \\
\text { and anti-estrogen agents in advanced } \\
\text { or metastatic HR-positive } \\
\text { and HER2-negative patients. }\end{array}$ & NCT03280563 & I \\
\hline
\end{tabular}

\section{PI3K/AKT/mTOR Pathway Inhibitors}

Cell growth, survival, motility angiogenesis, and metabolism are regulated by the phosphatidylinositol 3-kinase (PI3K)/protein kinase B (AKT)/mammalian target of rapamycin (mTOR) pathway [20]. Activation of this pathway leads to tumor development and drug resistance [21]. Over $70 \%$ of $B C$ cases have shown activation of this pathway. Binding of growth factor to the G-protein-coupled receptor or the tyrosine-kinase receptor activates the PI3K-AKT-mTOR pathway [20]. The PI3K complex has p110 $\alpha$, 
which is a catalytic subunit, and p85, which is a regulatory subunit. The subclasses PI3K $\alpha, \beta$, and $\delta$ are associated strongly in carcinogenesis promotion [22,23]. The mechanism of the PI3K-AKT-mTOR pathway is shown in Figure 3. The activation of this pathway leads to the phosphorylation of intracellular phosphatidylinositol-4,5-bisphosphate (PI-4,5-P2) to phosphatidylinositol-3,4,5-trisphosphate (PIP3), which is brought about by PI3K and later binds to pleckstrin-homology domains of AKT (a serine-threonine protein kinase) and other proteins [24]. Following this, AKT is activated on threonine residues (308 and 473 positions) induced by PI3. This AKT, in turn, activates mTORC1. mTORC1 is a complex molecule comprised of mTOR and protein, namely, Rheb, mLST8/G $\beta L$, PRAS40, and DEPTOR. The activated mTORC1 interacts with ribosomal protein S6 kinase (rpS6K) and eukaryotic translation initiation factor $4 \mathrm{E} 1$ binding protein (4E-BP1). These nuclear genes undertake the translation of genes responsible for cell proliferation and survival. Another complex, mTORC2, also contributes to AKT pathway activation via the phosphorylation of its serine residue at 473 position [20,22,25-27].

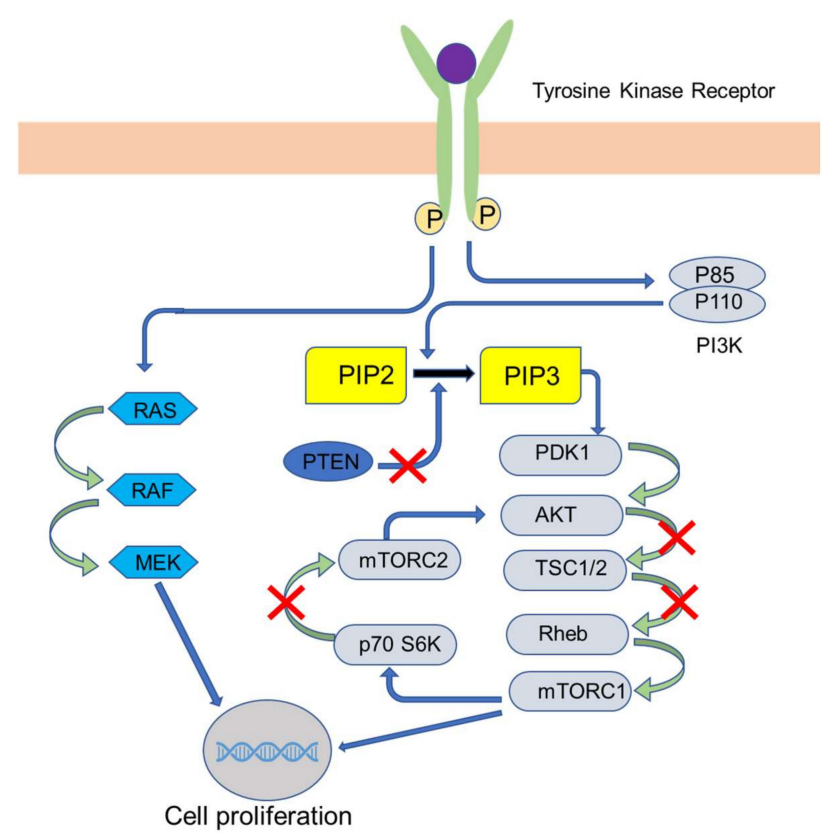

Figure 3. Schematic representation of the mechanism of the phosphatidylinositol 3-kinase (PI3K)/protein kinase B (AKT)/mammalian target of rapamycin (mTOR) pathway. PI3K-phosphatidylinositol 3-kinase, PIP - phosphatidylinositol-3,4,5-trisphosphate, PTEN-phosphatase and tensin homolog, PDK - phosphoinositide-dependent protein kinase, AKT—a serine/threonine-specific protein kinase, TSC-tuberous sclerosis protein, Rheb-Ras homolog enriched in brain, MTORC1-mammalian target of rapamycin complex-1, RAF-an acronym for rapidly accelerated fibrosarcoma, MEK-mitogen-activated protein kinase.

PI3K-AKT-mTOR pathway inhibitors can be classified as single inhibitors that block either AKT, mTOR, or PI3K and dual inhibitors that block two receptors, namely, mTORC1/mTORC2 and PI3K/mTOR [28-30]. The drugs, along with its mechanism of action on the receptors, are presented in Table 3.

Table 3. PI3K-AKT-mTOR pathway inhibitors.

\begin{tabular}{ccc}
\hline Receptor & Drugs & Mechanism of Action \\
\hline PI3K & Taselisib (GDC0032), pilaralisib (XL147), alpelisib (BYL719), buparlisib & PI3K inhibition \\
\hline AKT & $\begin{array}{c}\text { Capivasertib (AZD5363), uprosertib (GSK2141795), } \\
\text { miransertib (ARQ092), MK2206 }\end{array}$ & Inhibition of AKT 1,2,3 isoforms \\
\hline mTORC1 & Sirolimus, ridaforolimus, everolimus, temsirolimus & Allosteric inhibition of mTORC1 \\
\hline PI3K and mTOR & Dactolisib (NVP-BEZ235), gedatolisib (PF05212384), LY3023414 & Dual inactivation of PI3K and mTOR \\
\hline mTORC1 and mTORC2 & Vistusertib (AZD2014), sapanisertib (TAK-228), CC-223, AZD8055, MLN0138, & Allosteric inhibition of mTORC1 and mTORC2 \\
\hline
\end{tabular}


The combination therapy constituting PI3K/AKT/mTOR inhibitors with other chemotherapeutic agents like paclitaxel and monoclonal antibodies like trastuzumab have shown promising results in HER-positive/HR-positive BC [31-33]. The drugs explored for the combination therapy, and newer drugs that are under clinical development, are summarized in Table 4.

\section{Steroid Sulfatase Inhibitors}

Steroid sulfatase enzyme is the chief cause of the conversion of inactive sulfate conjugated steroid into the active and free form [34]. It is found that estrogenic steroids may initiate the growth of cancerous cells in the breast. So, the best approach to arrest this is by inhibiting steroid sulfatase. The combination of irosustat with aromatase inhibitor therapy has shown promising clinical advantage with a satisfactory safety profile. However, the results suggested that a more detailed clinical study is essential to ascertain the success and to enable its effective clinical translation [34,35].

\subsubsection{Therapy for HER2 Positive Breast Cancers}

\section{PI3K/AKT/mTOR Inhibitors}

PI3K inhibitors showed the best results in combination with lapatinib in treating patients suffering from HER2-positive advanced BC [36]. AKT inhibitors, along with trastuzumab, demonstrated significant antitumor activity [37]. The mTOR inhibitors, sirolimus [38] and ridaforolimus [39], along with trastuzumab, showed significant efficacy in HER2-positive BC therapy. However, activation of signaling pathways, including the PI3K/AKT/mTOR-pathway, has resulted in the development of resistance. The drug everolimus, an inhibitor of this pathway in combination with trastuzumab, has demonstrated a promising outcome in the advanced disease stage [40].

\section{Monoclonal Antibodies (MAbs)}

MAbs exert their action by targeting receptors and disrupting their signaling pathways. They target the cells via the immune system. Pertuzumab, trastuzumab, and margetuximab are the three MAbs currently available to treat BC, HER2-expressing tumors in particular. Trastuzumab acts by binding to the ectodomain of HER2 and blocks HER2 homodimerization, whereas pertuzumab acts by binding to subdomain-II of HER2 and prevents heterodimerization with HER3 [41]. Trastuzumab remains the mainstay of therapy for HER2-positive patients. As per the current treatment guidelines, trastuzumab, in combination with other chemotherapeutic agents, is recommended for a year. Pertuzumab, along with trastuzumab, in combination with additional chemotherapy, is recommended for patients with a high risk of cancer recurrence [42]. Margetuximab is a novel Fc-engineered HER2-targeted antibody that acts by the same mechanism as that of trastuzumab. It has a substitution of five amino acids at the IgG1-Fc (immunoglobulin class G1-crystallizable fragment) domain. Because of this modification, margetuximab has a higher affinity for Fc-receptors, which leads to increased antibody-dependent cell-mediated cytotoxicity [43]. As a single agent, margetuximab showed promising activity in phase I trial patients with HER2-positive MBC [44]. It has revealed a better overall response rate and longer median progression-free survival in the SOPHIA trial-phase III, which was conducted to compare margetuximab with trastuzumab, in combination with chemotherapy, in patients who have been previously treated with anti-HER2 targeted therapy (Clinical trial ID-NCT02492711). MAbs, along with other anticancer agents, has shown promising activity with reduced side effects, as compared to a single treatment. As cancer cells are continually undergoing mutation, there are higher chances that these may develop resistance to targeted therapy, such as MAbs. Cancer cells develop new checkpoint targets and antigens as they undergo mutation. Modern techniques like cancer genome sequencing can be utilized to study new targets for MAbs therapy, which may lead to the development of more effective MAbs [45]. 
Table 4. List of drugs/combinations of PI3K/AKT/mTOR inhibitors and other agents under clinical trials.

\begin{tabular}{|c|c|c|c|c|c|}
\hline Drug & Combination With & Study Arm & Description & ClinicalTrials.Gov Identifier: NCT Number & Phase \\
\hline Taselisib & $\begin{array}{l}\text { Taselisib, trastuzumab emtansine, } \\
\text { pertuzumab, } \\
\text { trastuzumab } \\
\text { paclitaxel }\end{array}$ & $\begin{array}{c}\text { Arm A: Taselisib with trastuzumab emtansine } \\
\text { Arm B: Taselisib with trastuzumab emtansine } \\
\text { and pertuzumab } \\
\text { Arm C: Taselisib with pertuzumab and trastuzumab } \\
\text { Arm D: Taselisib with pertuzumab, trastuzumab, } \\
\text { and paclitaxel }\end{array}$ & $\begin{array}{l}\text { Combination of taselisib (GDC-0032) with } \\
\text { anti-HER2 therapies in participants with } \\
\text { advanced HER2+ breast cancer-a Phase Ib } \\
\text { dose-escalation trial }\end{array}$ & NCT02390427 & $\mathrm{Ib}$ \\
\hline Pilaralisib (XL147) & Letrozole (Femara) & Arm A: Pilaralisib with letrozole & $\begin{array}{l}\text { A Phase 1/2 dose-escalation study of XL147 } \\
\text { (SAR245408), or XL765 (SAR2454409) in } \\
\text { combination with letrozole performed on } \\
\text { subjects with hormone receptor-positive } \\
\text { and HER2-negative breast cancer refractory to a } \\
\text { nonsteroidal aromatase inhibitor }\end{array}$ & NCT01082068 & Completed \\
\hline Pilaralisib (XL147) & $\begin{array}{l}\text { Trastuzumab, } \\
\text { Paclitaxel }\end{array}$ & $\begin{array}{l}\text { Arm A: Pilaralisib with trastuzumab } \\
\text { Arm B: Pilaralisib with trastuzumab and paclitaxel }\end{array}$ & $\begin{array}{c}\text { To study the efficacy of a combination of } \\
\text { pilaralisib with trastuzumab or paclitaxel } \\
\text { and trastuzumab in patients with metastatic -BC }\end{array}$ & NCT01042925 & Completed \\
\hline Alpelisib (BYL719) & Fulvestrant & $\begin{array}{l}\text { Arm A: Alpelisib ( } 300 \mathrm{mg} \text {; oral; once daily with } \\
\text { fulvestrant (500 mg; IM-injection) }\end{array}$ & $\begin{array}{l}\text { To assess the safety and efficacy in men } \\
\text { and postmenopausal women patients with } \\
\text { advanced-BC }\end{array}$ & NCT02437318 & III \\
\hline Alpelisib & Fulvestrant & $\begin{array}{l}\text { Arm A: Alpelisib } 300 \mathrm{mg} \text { oral daily with fulvestrant } \\
500 \mathrm{mg} \text { intramuscular on in first cycle } 1 \text { st day } \\
\text { and } 15 \text { th day, and thereafter every } 28 \text {-day cycle. }\end{array}$ & $\begin{array}{l}\text { To study the molecular features in HR-positive } \\
\text { and HER2-negative postmenopausal women } \\
\text { with a PIK3CA mutation }\end{array}$ & NCT03439046 & III \\
\hline MK2206 & & Arm A: MK-2206 mg orally once a week & $\begin{array}{l}\text { To study the efficacy of MK2206, an AKT } \\
\text { inhibitor in patients with advanced BC } \\
\text { and having AKT mutation and/or PTEN } \\
\text { Loss/PTEN mutation and/or PIK3CA mutation }\end{array}$ & NCT01277757 & Completed \\
\hline Everolimus, & Letrozole, everolimus, TRC105 & $\begin{array}{c}\text { Arm A: Letrozole } 2.5 \mathrm{mg}+\text { everolimus } 5 \mathrm{mg}+ \\
\text { TRC105 } 15 \mathrm{mg} / \mathrm{kg} \text { i.v } \\
\text { Arm B: Letrozole } 2.5 \mathrm{mg}+\text { everolimus } 10 \mathrm{mg}+ \\
\text { TRC105 } 15 \mathrm{mg} / \mathrm{kg} \text { i.v } \\
\text { Arm C: Letrozole } 2.5 \mathrm{mg}+\text { everolimus } 5 \mathrm{mg}+10 \\
\mathrm{mg} / \mathrm{kg} \text { i.v } \\
\text { Arm D: Letrozole } 2.5 \mathrm{mg}+5 \mathrm{or} 10 \mathrm{mg}+\mathrm{TRC} 10515 \mathrm{or} \\
\quad 10 \mathrm{mg} / \mathrm{kg} \text { i.v. }\end{array}$ & $\begin{array}{l}\text { To study how well a combination of letrozole, } \\
\text { TRC105 everolimus works in patients with stage } \\
2 \text { and } 3 \mathrm{BC} \text {, and how well it is tolerated }\end{array}$ & NCT02520063 & I/II \\
\hline Everolimus & Palbociclib, exemestane & $\begin{array}{l}\text { Palbociclib, everolimus, exemestane are administered } \\
\text { in a cycle of } 28 \text { days }\end{array}$ & $\begin{array}{l}\text { To study the efficacy of a combination of } \\
\text { palbociclib, everolimus, exemestane in } \\
\text { HR-positive and HER2-negative patients with } \\
\text { metastatic-BC }\end{array}$ & NCT02871791 & I/II \\
\hline Temsirolimus & $\begin{array}{l}\text { Bevacizumab, cetuximab } \\
\text { valproic acid }\end{array}$ & $\begin{array}{l}\text { Arm A: Temsirolimus, bevacizumab, cetuximab } \\
\text { Arm B: Temsirolimus, bevacizumab, valproic acid } \\
\text { Arm C: temsirolimus, bevacizumab }\end{array}$ & $\begin{array}{c}\text { To study the efficacy of bevacizumab } \\
\text { and temsirolimus alone or combination with } \\
\text { valproic acid or cetuximab in patients with } \\
\text { advanced or metastatic- BC }\end{array}$ & NCT01552434 & I \\
\hline Gedatolisib (PF05212384) & Trastuzumab biosimilar (herzuma) & Arm A: Herzuma + Gedatolisib & $\begin{array}{c}\text { To evaluate the safety and antitumor activity of } \\
\text { Herzuma }{ }^{\circledR} \text { with gedatolisib in HER-2 positive } \\
\text { patients with metastatic-BC }\end{array}$ & NCT03698383 & II \\
\hline Vistusertib (AZD2014) & Palbociclib, fulvestrant & $\begin{array}{c}\text { Arm A: A triple combination of AZD2014 + } \\
\text { palbociclib +fulvestrant }\end{array}$ & $\begin{array}{c}\text { To study the efficacy of a combination of } \\
\text { AZD2014, palbociclib, fulvestrant, in ER-positive } \\
\text { patients with metastatic-BC }\end{array}$ & NCT02599714 & I \\
\hline
\end{tabular}


Tyrosine Kinase (TK) Inhibitors

Neratinib, an irreversible pan-HER TK inhibitor, is used to reduce the chances of recurrence when given as adjuvant therapy in the early stage of HER2-positive BC. Neratinib is more efficient in blocking HER2 compared to trastuzumab, which may be the reason for its improved clinical outcome [46,47]. Neratinib alone (Clinical trial ID-NCT02673398) and in combination with T-DM1, capecitabine, and fulvestrant (NCT03377387, NCT02236000, NCT03289039) are currently under clinical development to evaluate the efficacy of these drugs. Neratinib has shown positive results in the NALA phase III trial (NCT01808573), which was conducted to assess the combined effect of capecitabine with neratinib versus capecitabine with lapatinib.

US FDA approved neratinib for the treatment of HER2 positive BC in Feb 2020 [48]. New TK inhibitors, namely, poziotinib, tucatinib, and pyrotinib, are presently under clinical development. Of these, pyrotinib and poziotinib, which belong to the irreversible pan-HER kinase inhibitor category, have shown significant toxicity in phase I and II trials [49]. Poziotinib, in the phase II trial, was administered as monotherapy after two lines of anti-HER2 therapy (namely, T-DM1, trastuzumab, pertuzumab, lapatinib), which showed activity by providing four months of median progression-free survival (PFS) [50]. Pyrotinib monotherapy under the same conditions has shown an overall response rate (ORR) and clinical benefit rate (CBR) of 50\% and 61\%, respectively [49]. Pyrotinib with capecitabine showed significant efficacy with ORR and median PFS of 78.5\% and 18 months, respectively, compared to the combination treatment of capecitabine with lapatinib in patients with HER2-positive metastatic-BC [51]. Other clinical trials (NCT02659514, NCT02544997) are ongoing to investigate the efficacy of poziotinib in HER2-positive MBC. Tucatinib inhibits HER2 selectively, with least/no inhibition of EGFR. Tucatinib is currently in a phase Ib clinical trial in combination with trastuzumab or capecitabine or both. It has shown significant benefits of ORR and median PFS of $61 \%$ and 10 months, respectively, in pretreated HER2 BC patients [52]. Studies have revealed that tucatinib has the ability to cross the blood-brain barrier. Currently, it is under clinical trial (NCT02614794) in combination with capecitabine, along with trastuzumab with or without tucatinib, in patients with HER2-positive metastatic-BC, with or without metastasis of brain, after prior treatment with T-DM1, pertuzumab, and trastuzumab [53].

\section{Antibody-Drug Conjugates (ADCs)}

ADCs are the new class of prodrugs in which a cytotoxic drug is coupled with MAbs. ADCs are highly selective to tumor cells and can hence reduce systemic toxicity [54,55]. T-DM1, emtansine combined with trastuzumab, is the first ADC approved by the US FDA to treat HER2-positive BC. DS-8201a, an ADC comprising of deruxtecan, a topoisomerase-1 inhibitor coupled with HER2-targeting antibodies, showed an ORR and disease control rate of $64.2 \%$ and $94 \%$, respectively, in a phase I clinical trial with HER2-positive and HER2-negative low metastatic-BC patients [56]. Two different phase III clinical trials to study the efficacy of DS-8201a are currently under investigation: NCT03523585, designed for the comparison of DS-8201 a with capecitabine, trastuzumab, and lapatinib in HER2 BC patients treated with T-DM1 previously, and NCT03529110, which compares the efficacy and safety of DS-8201a and T-DM1 in the HER2 BC patients treated with taxane [57]. SYD985 is another novel ADC developed by conjugating duocarmazine with trastuzumab via a linker. SYD985, when compared with T-DM1, showed a greater antitumor effect in preclinical studies [58], with encouraging results in a phase I clinical study [59]. NCT03262935, a phase III study in HER2-positive BC patients, wherein SYD985 is being compared with the physician's current treatment choice, is presently being investigated. On similar lines, two other ADCs, namely, XMT-1522 (auristatin conjugated with anti-HER2 antibody) and RC48 (E-derivative of auristatin conjugated with anti-HER2 MAb hertuzumab) are currently under phase I clinical trials, which have shown a good CBR [60,61]. Efforts were made to target two different epitopes of HER2 (bi-specific ADC MEDI4276), which failed to show a positive outcome in phase I and, hence, was out of the race [62]. 
Immunotherapy

Immunotherapy has recently emerged as one of the promising therapeutic approaches for BC. Many studies have been undertaken in this regard; for example, a recombinant molecule (HER2-Fc) was developed for targeting human dendritic cells. This recombinant protein has shown to provoke the immune response of T-cells against HER2 positive BC [63]. CD8 positive T-cell vaccines are shown to have significant anti-breast cancer activity. Preclinical data revealed that trastuzumab amplified the chances of tumor cell death by the vaccine CD8 positive T-cells, giving a hint to go ahead with the study. The study was carried out on healthy subjects, human leukocyte antigen A2-positive and A3-positive, and HER2-positive BC patients. Healthy subjects were vaccinated with trastuzumab, and patients were administered with a monthly dose of GP2-positive granulocyte-macrophage colony-stimulating factor (GM-CSF), followed by trastuzumab, for the next six months. In addition to the left ventricular ejection fraction (LVEF), local and systemic toxicity was observed. The outcome of the study revealed that the GP2-positive GM-CSF vaccine was found to be safe to be administered along with trastuzumab, and they were found to stimulate an immunologic response [64].

\subsubsection{Therapy of TNBC}

TNBC is the most aggressive form of breast cancer with higher rates of recurrence. Two genes, namely, BRCA1 and BRCA2, are said to be associated with TNBC. These genes are involved in the repair of DNA abnormalities, which lead to cancer development and the uncontrolled growth of the tumor. Hence, they are also called tumor suppressor genes [65,66]. A mutation or defect in the BRCA gene leads to the stoppage of its activity of repairing DNA sequence and preventing cancer, which leads to the development of TNBC [67]. Around 55-65\% and $45 \%$ of women with BRCA1 and BRCA2 mutations, respectively, will develop breast cancer. The recurrence of breast cancer in BRCA-mutated patients after first-time treatment is higher than average [66]. The patients with a BRCA1 mutation are more likely to develop TNBC and high tumor burden when compared to patients with BRCA2-mutated genes $[66,68]$. Approximately $5 \%$ of TNBC patients have a BRCA mutation, out of which $40-50 \%$ of the patients are BRCA1 mutated [69,70]. The patients with BRCA1-mutated TNBC show a higher number of tumor-infiltrating lymphocytes, high programmed cell death protein-1 (PD-1) and cytotoxic T-lymphocyte-associated protein 4 (CTLA-4) expression when compared with BRCA-1 nonmutated TNBC [71]. As cancer cell growth does not depend on hormones in TNBC, patients are unlikely to respond to hormone therapy, and hence, alternate options such as surgery and radiation along with chemotherapy are being adopted [72,73].

Immune checkpoint inhibitors (antibodies against PD-1 and CTLA-4) with cisplatin have been explored for the treatment of patients suffering from TNBC with a BRCA1 mutation. This has shown significant shrinkage of tumors and a high survival rate. Novel targeted therapies using poly (ADP-ribose) polymerase (PARP) inhibitors such as talazoparib, olaparib, and niraparib, in combination with immune checkpoint inhibitors, have shown positive clinical outcomes in patients [74,75]. Many other drugs that have additional immunotherapy benefits, along with their cytotoxic activity, are widely used for the treatment of TNBC, namely, anthracyclines, taxanes, cyclophosphamide, gemcitabine, and platinum salts. Anthracyclines activate dendritic cells and specific T-cells and increase CD8 T-cells, which are instigated by the apoptosis of cancer cells caused by anthracyclines [76]. The patients treated with taxanes have shown an increase in the number of tumor-infiltrating lymphocytes (TIL) [77]. They partially reduce the immunosuppression in the microenvironment of the tumor by selectively decreasing myeloid-derived suppressor cells (MDSCs) and regulatory T-cells [78-80]. Cyclophosphamide exerts its action by suppressing regulatory T-cells, inducing immunological cell death, and increasing the proliferation of natural killer and CD8 T-cells [81,82]. Gemcitabine helps in increasing the CD8 T-cells' anti-tumor activity and can also reduce MDSC counts [83,84], while platinum salts promote T-cell activation and induce immunologic cell death [85-87]. 
Poly (ADP-ribose) Polymerase (PARP) Inhibitors

Owing to its heterogeneity, the diagnosis and treatment of TNBC is challenging. Standard chemotherapy, comprising of a combination of a drug containing platinum, is recommended by the physicians. PARP inhibitors are the most novel, promising agents that have shown positive outcomes in both BRCA-associated and sporadic TNBC. Carboplatin and PARP inhibitors, when used in combination, can target the impaired DNA repair pathway in patients with BRCA1/2 mutations. PARP and BRCA1/2 have the basic difference of repairing ssDNA (single-stranded deoxyribonucleic acid) breaks and dsDNA (double-stranded deoxyribonucleic acid) breaks, respectively, through homologous recombination [88]. Olaparib, a PARP inhibitor, in phase III clinical trial, has shown the lowered risk of death and an improved median of $42 \%$ and 2.8 months when compared with standard chemotherapy [69]. Talazoparib (BMN 673), which is currently in phase II clinical trials (NCT01945775), has shown significant benefit as a single agent when compared with standard chemotherapy in germline BRCA1/2-mutated advanced-BC patients. The ability of it to trap the PARP-DNA complex by actively binding to the DNA makes it clinically significant [89]. Other PARP inhibitors such as veliparib (in phase III clinical trial, NCT02163694), niraparib (in phase III clinical trial, NCT01905592), and rucaparib (in phase II clinical trial, NCT02505048) are under investigation in germline BRCA1/2-mutated and advanced-BC patients. The responsiveness of the TNBC to PARP inhibitors or platinum therapy is based on three DNA-based homologous recombination deficiency scores, which reflect BRCA1/2 genetic defects [90].

\section{Anti-Angiogenic Agents}

Vascular endothelial growth factor (VEGF), an angiogenic factor, is one of the significant markers in TNBC. VEGF is expressed in the intratumoral region, and to treat this subtype, bevacizumab, $\mathrm{a} \mathrm{MAb}$, is used. These antibodies act by inhibiting metastasis and suppressing tumor neovasculature. According to the results of preclinical studies, bevacizumab, when added with docetaxel (a first-line chemotherapy drug), showed a significant response rate in the patient [91,92]. Bromodomain extraterminal (BET) proteins coordinate transcription by identifying specifically acetylated lysine on chromatin. BETi (BET inhibitor) competes with the procedure of suppressing the gene expression. Hypoxia allows the progression of TNBC. Thus, BETi, along with JQ1 (a thienotriazolo diazepine and potent inhibitor of BET family, named after its developer Jun Qi), were studied to express anticancer activity. JQ1 was successful in modulating cancer activity by downregulation, together with CA9 and VEGF-A. In addition, JQ1 prevented hypoxia-inducible factor (HIF) binding to the hypoxia response element in CA8. JQ1 has also been reported to reduce TNBC growth both in vitro and in vivo, and, therefore, JQ1, along with BETi, have demonstrated good antitumor activity [93].

\section{Immunotherapy}

PD-1 and PD-L1 (PD-ligand1) are the proteins present on T-cells and healthy cells (and more in number on cancer cells), respectively. PD-1, a programmed cell death receptor, is involved in the suppression of T-cells. They accomplish this by inhibiting the auto-immune response of T-cells and prevent them from acting against killer cancer cells [94]. Atezolizumab, an anti-PD-L1 antibody along with Nab-paclitaxel (Abraxane ${ }^{\circledR}$ ), was approved by the US FDA in 2019 for unresectable locally advanced or metastatic TNBC [95]. Trials are currently underway in patients with a positive PD-L1 response, for example, pembrolizumab, a human MAb that has demonstrated durable anticancer activity $[92,96,97]$. In another study, an mRNA vaccine incorporated into nanoparticles (NPs) to act against tumor antigen MUC1 on dendritic cells (DCs) in lymph nodes was developed. The anti-CTLA-4 (cytotoxic T-lymphocyte associated protein-4) monoclonal antibody was added to the mRNA vaccine to increase its activity against cancer. In vivo studies were carried out, which showed that the vaccine targeted mannose receptors on DCs and exhibited anticancer activity against TNBC 4T1 cells. It also 
showed that the combination therapy had an additional antitumor activity, rather than the vaccine alone [64].

\section{Monoclonal Antibody}

MAbs are emerging as an exciting alternative for the treatment of TNBC. A protein, glycoprotein NMB (transmembrane glycoprotein), is overexpressed in TNBC. This protein is related to the invasion of the tumor and cell metastasis, as it is a transmembrane protein. A monoclonal antibody-cytotoxic drug (glembatumumab vedotin) was formulated to target this protein directly, and this trial has shown positive results in cancer treatment [98]. Inhibition of PD-1 or PD-L1 has demonstrated anticancer activity in treating metastatic breast cancer (MBC). Researchers measured the response of the drug avelumab, a PD-L1 inhibitor, in patients affected with MBC. In phase I studies, patients received standard intravenous avelumab therapy every two weeks. Tumors were observed for every six weeks, and immunohistochemistry was performed to examine the expression of the membrane PD-L1. In a subset of MBC patients, avelumab showed a tolerable safety profile and clinical activity [99]. Table 5 presents a list of drugs for TNBC therapy that are currently under clinical investigation.

\section{RANKL and RANK System}

The tumor necrosis factor (TNF) is involved in various cellular events such as cell differentiation, proliferation, survival, and death. Inflammatory cells secrete the TNF is a type of inflammation-associated carcinogenesis [100]. RANKL (receptor activator nuclear factor- $\mathrm{kB}$ ligand) is a member of TNF $\alpha$ that binds to RANK (receptor activator of nuclear factor- $\mathrm{kB}$ ), a membrane receptor. The binding of RANKL to RANK receptor promotes the proliferation of mammary epithelial cells and development of tubuloalveolar mammary tissue [101]. RANK promotes tumorigenesis in epithelial cells of breast tissue by causing a transition in epithelial-mesenchymal cells. Along with the hormone-dependent RANK/RANKL effect, RANKL is also capable of forming breast tumors, followed by metastasis [102]. Identification of this pathway and its role in breast cancer development has paved the way for its possible utilization as a potential target for breast cancer therapy. The mechanism is presented in Figure 4. The RANK/RANKL pathway can be blocked by using an antibody that can selectively block RANK and prevent the attachment of RANKL to RANK receptors, thereby preventing the activation of RANK. Denosumab, a monoclonal antibody for RANK at present, is used for treating osteoporosis [103]. Blocking the RANK/RANKL pathway also reduces the risk of BC development in postmenopausal women [102,104]. Studies are still underway to define the mechanism of this pathway in BC development, which, if proved, could be a novel target.

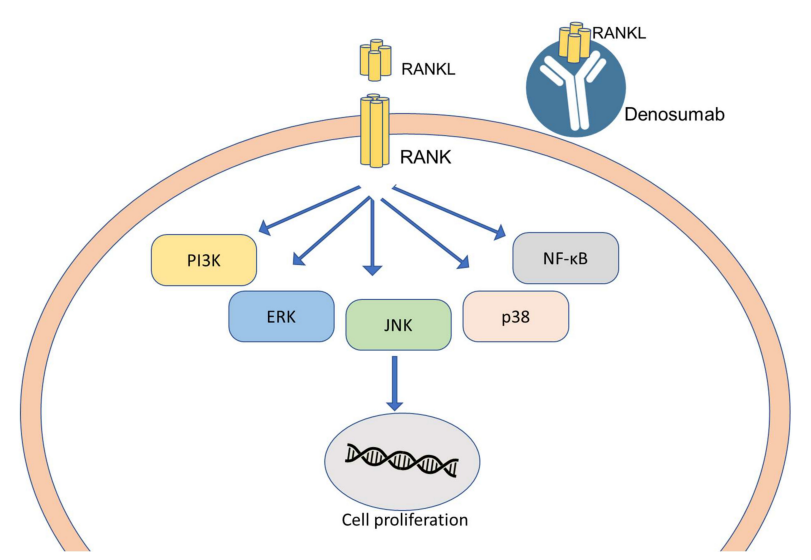

Figure 4. Schematic representation of the RANK/RANKL pathway. Pathways activated by RANK-RANKL signaling and downstream targets. ERK = extracellular signal-related kinases; $\mathrm{JNK}=$ cJun amino-terminal kinases; NF- $\mathrm{KB}=$ nuclear factor $\mathrm{\kappa B}$; PI3K = phosphoinositide 3-kinase; RANK = receptor activator of nuclear factor $\mathrm{kB}$; RANKL = receptor activator of nuclear factor $\mathrm{kB}$ ligand; TRAF $=$ TNF receptor-associated factor. 
Table 5. List of drugs under clinical trials for the treatment of TNBC.

\begin{tabular}{|c|c|c|c|c|c|}
\hline Drug & Combination With & Study Arm & Description & $\begin{array}{l}\text { ClinicalTrials.Gov Identifier: } \\
\text { NCT Number }\end{array}$ & Phase \\
\hline Cisplatin & Romidepsin, nivolumab & $\begin{array}{l}\text { Arm A: cisplatin }\left(75 \mathrm{mg} / \mathrm{m}^{2}\right)+\text { romidepsin }\left(8 \mathrm{mg} / \mathrm{m}^{2}\right) \\
\text { Arm B: romidepsin }\left(10 \mathrm{mg} / \mathrm{m}^{2}\right)+\text { cisplatin }\left(75 \mathrm{mg} / \mathrm{m}^{2}\right) \\
\text { Arm C: romidepsin }\left(12 \mathrm{mg} / \mathrm{m}^{2}\right)+\text { cisplatin }\left(75 \mathrm{mg} / \mathrm{m}^{2}\right) \\
\text { Arm D: romidepsin MTD (maximum tolerable dose })+ \\
\text { cisplatin }\left(75 \mathrm{mg} / \mathrm{m}^{2}\right)+\text { nivolumab } 360 \mathrm{mg}\end{array}$ & $\begin{array}{l}\text { To study the efficacy of cisplatin in combination with } \\
\text { romidepsin and nivolumab in patients with TNBC or } \\
\text { BRCA mutation or metastatic-BC }\end{array}$ & NCT02393794 & $\mathrm{I} / \mathrm{II}$ \\
\hline MM-310 & & Arm A: MM-310 i.v., 21-day cycle. & $\begin{array}{l}\text { MM-310 is a docetaxel loaded liposomal formulation } \\
\text { with targeting ability of EphA2 receptor. } \\
\text { In this study, safety and efficacy of MM-310 in } \\
\text { patients with TNBC was studied }\end{array}$ & NCT03076372 & I \\
\hline Carboplatin & Everolimus & $\begin{array}{l}\text { Arm A: Carboplatin alone } \\
\text { Arm B: Carboplatin + everolimus }\end{array}$ & $\begin{array}{l}\text { To study the safety and efficacy of carboplatin alone } \\
\text { and carboplatin in combination with everolimus in } \\
\text { patients with advanced TNBC }\end{array}$ & NCT02531932 & II \\
\hline Leronlimab & Carboplatin & $\begin{array}{l}\text { Arm A: leronlimab }(350 \mathrm{mg})+\text { AUC } 5 \text { carboplatin } \\
\text { Arm B: leronlimab }(525 \mathrm{mg})+\text { AUC } 5 \text { carboplatin } \\
\text { Arm C: leronlimab (700 mg) + AUC } 5 \text { carboplatin } \\
\text { Arm D: leronlimab (MTD) + AUC } 5 \text { carboplatin }\end{array}$ & $\begin{array}{l}\text { To study the safety and efficacy of leronlimab when } \\
\text { given in combination carboplatin in the patients with } \\
\text { advanced TNBC }\end{array}$ & NCT03838367 & $\mathrm{Ib} / \mathrm{II}$ \\
\hline Nab-Paclitaxel & Mifepristone & $\begin{array}{l}\text { Arm A: nab-paclitaxel } 100 \mathrm{mg}+\text { mifepristone } 300 \mathrm{mg} \\
\text { Arm B: nab-paclitaxel } 100 \mathrm{mg}+\text { placebo }\end{array}$ & $\begin{array}{l}\text { To study the efficacy of Nab-paclitaxel alone and in } \\
\text { combination with mifepristone in the glucocorticoid } \\
\text { receptor-positive and TNBC patients }\end{array}$ & NCT02788981 & II \\
\hline L-NMMA & $\begin{array}{c}\text { Docetaxel } \\
\text { amlodipine } \\
\text { pegfilgrastim } \\
\text { Enteric-coated aspirin }\end{array}$ & $\begin{array}{l}\text { Arm A: L-NMMA + docetaxel + } \\
\text { amlodipine + } \\
\text { pegfilgrastim + }+ \\
\text { Enteric-coated aspirin }\end{array}$ & $\begin{array}{l}\text { To study the L-NMMA's MTD, dose-limiting toxicities } \\
\text { and to find out the efficacy in combination with } \\
\text { docetaxel in patients with advanced TNBC }\end{array}$ & NCT02834403 & $\mathrm{Ib} / \mathrm{II}$ \\
\hline $\begin{array}{l}\text { Mirvetuximab } \\
\text { soravtansine }\end{array}$ & Gemcitabine hydrochloride & $\begin{array}{c}\text { Arm A: mirvetuximab soravtansine + gemcitabine } \\
\text { hydrochloride }\end{array}$ & $\begin{array}{l}\text { To study the dose-escalation, tolerability safety } \\
\text { and efficacy of mirvetuximab soravtansine in } \\
\text { combination with gemcitabine hydrochloride in } \\
\text { patients with folate receptor-positive ovarian } \\
\text { and TNBC }\end{array}$ & NCT02996825 & I \\
\hline Atezolizumab & Paclitaxel & $\begin{array}{l}\text { Arm A: atezolizumab }(840 \mathrm{mg}) \text { and paclitaxel }\left(90 \mathrm{mg} / \mathrm{m}^{2}\right) \\
\text { Arm B: placebo and paclitaxel }\left(90 \mathrm{mg} / \mathrm{m}^{2}\right)\end{array}$ & $\begin{array}{l}\text { To study the efficacy of a combination of a } \\
\text { PD-L1-antibody, atezolizumab, and paclitaxel in } \\
\text { advanced TNBC patients }\end{array}$ & NCT03125902 & III \\
\hline Tak-228 & $\begin{array}{c}\text { Tak-117 } \\
\text { Cisplatin } \\
\text { Nab-Paclitaxel }\end{array}$ & $\begin{array}{l}\text { Arm A: Tak-228 and Tak-117 followed by cisplatin } \\
\text { and nab-paclitaxel }\end{array}$ & $\begin{array}{l}\text { To study the efficacy of TAK- } 228 \text { and TAK- } 117 \\
\text { treatment followed by cisplatin and nab-paclitaxel } \\
\text { treatment in patients with metastatic TNBC }\end{array}$ & NCT03193853 & II \\
\hline Onalespib & paclitaxel & $\begin{array}{c}\text { Arm A: onalespib (i.v.) on day } 7+\text { paclitaxel (i.v.) days } 1 \\
\text { 8, and } 15 ; 28 \text {-day cycle }\end{array}$ & $\begin{array}{l}\text { To study the best dose and side effects of onalespib } \\
\text { when given in combination with paclitaxel in } \\
\text { advanced TNBC patients }\end{array}$ & NCT02474173 & I \\
\hline
\end{tabular}




\section{Multidrug-Resistant (MDR) BC}

Resistance to $B C$ therapy is one of the major obstacles that limit the effectiveness of the treatment in BC patients, leading to recurrence. Multidrug resistance refers to a condition where cancer cells develop cross-resistance to chemotherapeutic drugs due to a multitude of factors. Some of the patients develop resistance to certain medications before treatment, which may be attributed to their genetic makeup and is referred to as intrinsic drug resistance. Acquired resistance is a kind of resistance that a patient develops over a period of time following exposure to the treatment. This resistance is the main reason for the relapse of cancer even after the treatment or during the treatment. The main mechanisms of drug resistance are increased efflux of drugs, alteration of drug target, enhanced DNA damage repair, senescence escape, epigenetic modifications, tumor heterogeneity, changes in the tumor microenvironment, and epithelial-mesenchymal transition [105,106].

Valspodar (PSC833) is a P-glycoprotein inhibitor that plays a significant role in efflux-mediated MDR that has shown promising results by increasing mitoxantrone accumulation by $94 \%$ when administered before treatment with mitoxantrone [107]. Paclitaxel has shown improved effectiveness against MDR-BC in patients who were administered valspodar before treatment than those without valspodar administration (ClinicalTrials.gov Identifier: NCT00002826). Drugs such as docetaxel, laniquidar, and paclitaxel, when given in combination, have shown to combat MDR-BC in patients with metastatic-BC (ClinicalTrials.gov Identifier: NCT00028873). Photodynamic therapy is another novel strategy that has been explored and has proved to reverse MDR, possibly by inhibiting the pathways that are involved in MDR [108]. Lu Yang and co-workers in their studies showed that PEPDG278D, a recombinant peptidase, which has a strong affinity for the HER2-receptor, inhibits the same receptor. Preclinical studies conducted revealed high activity in trastuzumab and other anti-HER2-resistant BC [109]. Ritonavir, an antiretroviral drug, was shown to overcome drug resistance when administered along with other anticancer agents due to its ability to deactivate metabolizing enzymes and efflux transporters, which are overexpressed in MDR-BC [110].

\section{Nanomedicine Used in the Management of Breast Cancer}

Nanomedicine is a rapidly emerging field in the treatment of various diseases. It has shown promising results in cancer therapy by offering new alternatives to the currently existing diagnosis and therapies. Numerous nanoparticles have been developed with targeting properties towards cancer cells, along with metastatized breast cancer [111]. The nanoparticle formulations that have been approved are listed in Table 6.

Nanoparticles (NPs) offer many promising properties to active pharmaceutical ingredients, together with longer elimination time, increased drug-target interaction time, and reduced drug resistance. The advantage of NPs is increased drug interaction with the cancer-affected area and minimized drug resistance. The nanoparticle drug transporters encompass a minimum of two ingredients, one being the active pharmaceutical ingredient and the other being the carrier. NPs signify multipurpose tools to encapsulate a variety of medicine and can be custom-tailored for patients by simple conjugation methods [111-113]. Further subclassification is discussed in the following sections. The nanocarriers that have been explored for the treatment of BC are presented in Table 7. 
Table 6. List of approved nanotechnology-based cancer drug therapies.

\begin{tabular}{|c|c|c|c|c|c|c|c|c|}
\hline Product & Drug & Company & Nanoparticle & Composition & Particle Size & Indication & $\begin{array}{l}\text { Approval by US FDA } \\
\text { and others }\end{array}$ & Reference \\
\hline Genexol-PM & Paclitaxel & Samyang/Biopharm & PEG-PLA polymeric micelle & $\begin{array}{l}\text { Paclitaxel, monomethoxy poly (ethylene } \\
\text { glycol)-block-poly (D,L- lactide) }\end{array}$ & $23.91 \mathrm{~nm}$ & Breast, lung, ovarian cancer & $\begin{array}{c}2007 \\
\text { (South Korea) }\end{array}$ & [114-116] \\
\hline Abraxane & Paclitaxel & Abraxis/Celgene & Nanoparticle-bound albumin & Paclitaxel, human albumin & $130 \mathrm{~nm}$ & $\begin{array}{l}\text { In breast, pancreatic } \\
\text { and non-small cell } \\
\text { lung cancer }\end{array}$ & 2005 & {$[117,118]$} \\
\hline Doxil & Doxorubicin & Johnson and Johnson & Liposome & $\begin{array}{l}\text { N-(carbonyl-methoxypolyethylene glycol } \\
\text { 2000)-1,2-distearoyl-sn-glycero-3-phosphoethanolamine } \\
\text { sodium salt (DSF-PEG 2000), hydrogenated soy } \\
\text { phosphatidylcholine, and cholesterol }\end{array}$ & $85 \mathrm{~nm}$ & $\begin{array}{l}\text { Kaposi's sarcoma } \\
\text { Ovarian cancer } \\
\text { Breast cancer } \\
\text { Multiple myeloma }\end{array}$ & $\begin{array}{c}1995 \\
1999 \\
2003 \\
2007 \\
\text { (Europe, Canada) } \\
\end{array}$ & {$[119,120]$} \\
\hline Myocet & Doxorubicin & Cephalon & Liposome & $\begin{array}{l}\text { Egg phosphatidylcholine and cholesterol with } \\
\text { Doxorubicin citric acid aqueous core }\end{array}$ & $190 \mathrm{~nm}$ & Breast cancer & $\begin{array}{l}2000 \\
(\mathrm{EU})\end{array}$ & {$[119,120]$} \\
\hline Depocyt & Cytarabine & Pacira & Liposome & $\begin{array}{l}\text { Cholesterol, glycerol trioleate, triglyceride, } \\
\text { phospholipids (dipalmitoyl } \\
\text { phosphatidylglycerol), and dioleoyl } \\
\text { phosphatidylcholine }\end{array}$ & $20 \mu \mathrm{m}$ & Neoplastic meningitis & 1999 & [121-123] \\
\hline Lipo-Dox & Doxorubicin & Taiwan Liposome & Liposome & $\begin{array}{l}\text { Cholesterol, N-(carbonyl-ethoxypolyethylene } \\
\text { glycol } \\
\text { 2000)-1,2-distearoyl-sn-glycero-3-phosphoethanolamine, } \\
\text { hydrogenated soybean lecithin }\end{array}$ & $104.2 \mathrm{~nm}$ & Breast, ovarian cancer & $\begin{array}{l}1998 \\
\text { (Taiwan) }\end{array}$ & {$[124,125]$} \\
\hline DaunoXome & Daunorubicin & Galen & Liposome & Cholesterol, distearoylphosphatidylcholine & $45 \mathrm{~nm}$ & Kaposi's sarcoma & 1996 & {$[126,127]$} \\
\hline
\end{tabular}

Table 7. List of some nanomedicines explored for the treatment of breast cancer.

\begin{tabular}{|c|c|c|c|c|c|c|}
\hline Nanoparticle Type & Type of Breast Cancer & Therapeutic Agent & Materials Used & Entrapment Efficiency (EE) and Particle Size & Key Outcome & Reference \\
\hline Liposomes & luminal breast cancer & $\begin{array}{l}\text { Anti-IL6R antibody, } \\
\text { Doxorubicin }\end{array}$ & $\begin{array}{l}\text { Cholesterol, 1,2-dioleoyl-sn-glycero- } \\
\text { 3-phosphoethanolamine } \\
\text { 1,2-dioleoyl-sn-glycero-3-phosphocholine } \\
\text { In (1:1:1 molar ratio) }\end{array}$ & $85.81 \% \pm 0.4799 \%$ to $89.03 \% \pm 0.143 \%, \sim 100 \mathrm{~nm}$ & $\begin{array}{c}\text { Formulation showed an } \\
\text { enhanced tumor targeting } \\
\text { efficacy with anti-tumor } \\
\text { metastasis effects in BALB/c } \\
\text { mice bearing } 4 \mathrm{~T} 1 \text { cells } \\
\end{array}$ & [128] \\
\hline Liposomes & $\begin{array}{l}\text { Luminal breast cancer- } \\
\text { Estrogen positive BC }\end{array}$ & Doxorubicin & $\begin{array}{l}\text { Estrone conjugated DPPC and DSPE-PEG2000- } \\
\qquad \mathrm{NH}_{2} \text { liposomes }\end{array}$ & EE not reported, $194 \mathrm{~nm}$ & $\begin{array}{l}\text { Formulations showed } \\
\text { significant uptake in } \\
\text { ER-positive (MCF-7) and non- } \\
\text { significant uptake in } \\
\text { ER-negative (MDA-MB-231) } \\
\text { cell lines }\end{array}$ & [129] \\
\hline
\end{tabular}


Table 7. Cont.

\begin{tabular}{|c|c|c|c|c|c|c|}
\hline Nanoparticle Type & Type of Breast Cancer & Therapeutic Agent & Materials Used & Entrapment Efficiency (EE) and Particle Size & Key Outcome & Reference \\
\hline $\begin{array}{l}\text { Albumin } \\
\text { nanoparticles }\end{array}$ & HER2 positive BC & 2-methoxy-estradiol & Bovine serum albumin & $\begin{array}{c}89.85 \% \pm 3.80 \% \\
\text { to } 88.70 \% \pm 2.95 \%, \sim 238.8 \pm 5.1 \mathrm{~nm}\end{array}$ & $\begin{array}{l}\text { Formulated NPs showed } \\
\text { enhanced cytotoxicity } \\
\text { and cellular uthake when } \\
\text { compared with the free drug } \\
\text { when assessed in SK-BR-3 } \\
\text { and MCF-7 cell line } \\
\text { and SK-BR-3, MCF-7 } \\
\text { tumor-bearing mice }\end{array}$ & [130] \\
\hline $\begin{array}{c}\text { chitosan } \\
\text { nanoparticles }\end{array}$ & HER2 positive BC & doxorubicin & $\begin{array}{l}\text { O-succinyl chitosan graft Pluronici }{ }^{\circledR} \text { F127 and 5\% to 10\% } \\
\text { anti-HER2 peptide }\end{array}$ & $\begin{array}{l}73.69 \% \pm 0.53 \% \text { to } 74.65 \% \pm 0.44 \%, 34.92 \text { to } \\
50.79 \mathrm{~nm}\end{array}$ & $\begin{array}{l}\text { In vitro cytotoxicity } \\
\text { and cellular-uptake study were } \\
\text { performed on MCF-7 cell line } \\
\text { which showed that the NP } \\
\text { conjugated with anti-HER2 } \\
\text { showed higher cytotoxicity } \\
\text { when compared with free drug }\end{array}$ & [131] \\
\hline liposomal & HER2 positive BC & doxorubicin & $\begin{array}{l}\text { HER2pep-K3-palmitic acid conjugate, DSPC, } \\
\text { mPEG2000-DSPE }\end{array}$ & $>98 \%, \sim 80 \mathrm{~nm}$ & $\begin{array}{c}\text { In vitro cytotoxicity } \\
\text { and cellular-uptake studies } \\
\text { were performed on BT-474, } \\
\text { SK-BR-3 and MCF-7. } \\
\text { The formulation showed higher } \\
\text { cytotoxicity and cellular uptake } \\
\text { with lower systemic toxicity } \\
\text { when compared with free drug }\end{array}$ & [132] \\
\hline Iron oxide & HER2 positive BC & siRNA & $\begin{array}{l}\text { Iron oxide, caffeic acid, calcium phosphate } \\
\text { and PEG-polyanion block copolymer }\end{array}$ & EE not reported, $130 \mathrm{~nm}$ & $\begin{array}{c}\text { In vitro cytotoxicity } \\
\text { and cellular-uptake studies } \\
\text { were performed on HCC1954. } \\
\text { After treating with NP, HER2 } \\
\text { mRNA expression was } \\
\text { decreased by } 38 \% \text { when } \\
\text { compared with naked siRNA }\end{array}$ & [133] \\
\hline $\begin{array}{c}\text { Polymeric } \\
\text { nanoparticles }\end{array}$ & HER2 positive BC & Emtansine & $\begin{array}{l}\text { D- } \alpha \text {-tocopheryl polyethylene glycol } 1000 \text { succinate-poly } \\
\text { (D, L-lactide) }\end{array}$ & $84-94 \%, 102-125 \mathrm{~nm}$ & $\begin{array}{c}\text { In vitro cytotoxicity } \\
\text { and cellular-uptake studies } \\
\text { were performed on } \\
\text { MDA-MB-453 cell lines } \\
\text { and in vivo cytotoxicity study } \\
\text { in MDA-MB-453 xenograft } \\
\text { mice model. The nanoparticle } \\
\text { showed superior antitumor } \\
\text { effect when compared with } \\
\text { the free drug }\end{array}$ & [134] \\
\hline $\begin{array}{c}\text { Polymeric } \\
\text { nanoparticles }\end{array}$ & TNBC & Paclitaxel & Poly(lactic-co-glycolic acid) NP coated with hyaluronic acid & $84-98.34 \%, 225.1 \pm 0.43 \mathrm{~nm}$ & $\begin{array}{c}\text { In vitro cell viability } \\
\text { and cellular-uptake studies } \\
\text { were performed on } \\
\text { MDA-MB-231. The prepared } \\
\text { NP showed an improved } \\
\text { cellular uptake and thereby } \\
\text { higher cytotoxicity in cancer } \\
\text { cells when compared with } \\
\text { free drug }\end{array}$ & [135] \\
\hline
\end{tabular}


Table 7. Cont

\begin{tabular}{|c|c|c|c|c|c|c|}
\hline Nanoparticle Type & Type of Breast Cancer & Therapeutic Agent & Materials Used & Entrapment Efficiency (EE) and Particle Size & Key Outcome & Reference \\
\hline SLN & TNBC & Di-allyl-disulfide & $\begin{array}{l}\text { SLN prepared with palmitic acid, soya lecithin } \\
\text { and pluronic F-68 and surface modified with glycation end } \\
\text { products antibody }\end{array}$ & $79.23 \%, 116.20 \mathrm{~nm}$ & $\begin{array}{l}\text { Formulated NP demonstrated } \\
\text { a high cellular uptake by } \\
\text { MDA-MB231 cell line } \\
\text { and thereby reduction in } \\
\text { systemic side effect of the drug } \\
\text { and increased activity at } \\
\text { tumor site }\end{array}$ & [136] \\
\hline $\begin{array}{c}\text { Polymer } \\
\text { nanoparticles }\end{array}$ & TNBC & Curcumin, & Chitosan NPs with apoptosis-inducing ligand (TRAIL) & $51.67 \%, 652 \pm 10 \mathrm{~nm}$ & $\begin{array}{l}\text { The NPs showed a reduced } \\
\text { tumor volume when compared } \\
\text { to control when tested in } \\
\text { BALB/c mice }\end{array}$ & [137] \\
\hline Iron oxide NPs & TNBC & Baicalein & PEG-coated iron oxide magnetic nanoparticles & $95.3 \%, 100 \mathrm{~nm}$ & $\begin{array}{l}\text { Significantly inhibited } \\
\text { the MDA-MB-231 cell growth } \\
\text { when tested in vitro } \\
\text { and showed significant } \\
\text { anti-apoptotic activity } \\
\end{array}$ & [138] \\
\hline Polymeric NPs & TNBC & Thymoquinone & $\begin{array}{c}\text { Hyaluronic acid conjugated Pluronic }{ }^{\circledR} \text { P123 and Pluronic }{ }^{\circledR} \\
\text { F127 NPs }\end{array}$ & EE not reported, $22.0 \pm 3.1 \mathrm{~nm}$ & $\begin{array}{l}\text { Formulations retarded cell } \\
\text { growth and migration of } \\
\text { MDA-MB-231. Studies in } \\
\text { Balb/c mice showed significant } \\
\text { reduction in tumor load when } \\
\text { treated with formulations }\end{array}$ & [139] \\
\hline
\end{tabular}




\subsection{Polymer-Based Nanoparticles (PBNP)}

NPs containing polymer as an integral ingredient are known as polymeric NPs, which can be of either natural or artificial origin. Polymer-based nanoparticles (PBNPs) have the advantage of sustained drug delivery, long blood-circulation time, and can also be tuned for $\mathrm{pH}-$, radiation-, and temperature-responsiveness. When it comes to drug loading into the NPs, it can be done by two processes: the first being physical entrapment, and the second is covalent linking to the compound matrix [111]. Researchers have targeted essential genes responsible for the multiplication of cancerous cells. To achieve this goal, siRNA (small interfering RNA) was designed, which were delivered in vivo to inhibit the growth of cancerous cells. Here, a mesoporous silica NP core was loaded with crosslinking polyethyleneimine-polyethylene glycol copolymer loaded with siRNA to target HER2 oncogene. It was coupled with trastuzumab, a monoclonal antibody that increases the blood half-life of siRNA. Along with this property, specific uptake of nanoparticles by cancerous cells was also increased. It was observed that a single dose of siRNA nanoparticles showed a $60 \%$ decrease in HER2 protein levels in a trastuzumab-resistant xenograft. The study was continued for three weeks and showed significant inhibition in the growth of tumor cells. The prepared siHER2 NPs (siRNA NPs against HER2 designated siHER2 NP) showed a better safety profile and negligible cytokine induction in comparison to peripheral mononuclear cells [140]. In another study, poly(lactide-co-glycolide), poly(lactic acid), and poly(e-caprolactone) nanoparticles loaded with anastrozole, an anti-cancer drug, were developed. The prepared formulations were tested for its in vitro cytotoxicity and in vivo pharmacokinetics in rats. The entrapment efficiency of the formulations ranged between 35-85\%, which depended on the drug-polymer ratio. The area under the curve for nanoparticles prepared using three different carrier systems was higher when compared with anastrozole in solution. The pharmacokinetics of these polymeric nanoparticles have revealed the extended circulation of drugs and have proved effective in breast cancer chemotherapy [113,141]. In another study, the use of polymeric nanoparticles for TNBC therapy was explored using chitosan/polylactide nanoparticles loaded with tamoxifen, which showed significant activity against TNBC cells, causing cell death and cell arrest [142]. Researchers have explored PBNP not only for drug loading but also for theranostic purposes. Jin and co-workers conjugated luminescent poly[2-methoxy-5-(2-ethylhexyloxy)-1,4-phenylenevinylene] with the cyclic arginine-glycine-aspartic acid conjugated polymer nanoparticles, which generates reactive oxygen species (ROS) when irradiated with light and has shown promising results on MDA-MB-231 cells [143]. Nuannuan $\mathrm{Li}$ and co-workers synthesized $\mathrm{pH}$-sensitive self-assembling amphiphilic copolymers formulated into polymersomes by incorporating verapamil hydrochloride and doxorubicin hydrochloride, to overcome doxorubicin resistance in the MCF-7/ARD cell line [144]. Yao and co-workers fabricated multifunctional $\mathrm{pH}$-responsive nanocarriers for the delivery of anticancer drugs that constituted poly(2-(diisopropylamino)ethyl methacrylate) (PDPA) polymer as the inner core and amphiphilic lipid-poly(ethylene glycol) (lipid-PEG) as the outer shell, conjugated with iRGD peptide on the surface. The studies have suggested the plausible use of this novel platform for the effective treatment of cancer [145].

Micellar nanocarriers, another set of self-assembling colloidal systems comprising of a hydrophobic core with a hydrophilic shell made up of surfactant and hydrophilic polymers, have also been explored for breast cancer therapy. A new redox-sensitive micellar system consisting of hyaluronic acid (HA)-based amphiphilic conjugate (HA-ss-(OA-g-bPEI), HSOP) was formulated for tumor-based codelivery of paclitaxel (PTX) and AURKA-explicit siRNA (si-AURKA) for the treatment of targeted cancer therapy. HSOP showed outstanding loading for both PTX and siRNA, with regulating dosage ratios and necessary redox sensitivity individually. This was confirmed by morphological fluctuations of micelles with the in vitro release of both drugs in different reducing environments. The HSOP micelles were able to deliver both PTX and siRNA simultaneously into MDA-MB-231 BC cells via HA-receptor mediated endocytosis, followed by quick transport into the cytosol, which was confirmed by flow cytometry and confocal microscopic investigation. The synergistic effects between the drugs 
were enhanced by the specific delivery and transport when compared to single drug-loaded micelles and nonsensitive coloaded micelles, leading to significantly higher antitumor efficacy. The in vitro examination found that HSOP micelles could accumulate effectively in cancerous sites and had the maximum antitumor effectiveness over nonsensitive control of codelivery and redox-sensitive single-drug controls. The redox-sensitive HSOP codelivery system is promising in combining drug/gene therapy for targeting tumor therapy [146]. Studies have shown that the TNBC cells that are resistant to conventional chemotherapy can be photomechanically killed, with few laser beams using bioinspired-NPs [147]. Xie and co-workers formulated polymeric hybrid-nanomicelles for the codelivery of DOX/MiR-34a, with high tumor suppression and enhanced MRI in a BC mice model [148]

\subsection{Lipid-Based Drug Carriers}

Lipid-based NPs are the colloidal systems comprising of biocompatible lipid cores. These systems have the advantages of high biocompatibility, thermal stability, drug-loading efficiency, and sustained drug release. The lipid-based carriers include liposomes, solid lipid nanoparticles, and nanostructured lipid carriers. These carriers have the ability to transport hydrophobic as well as hydrophilic drugs with low toxicity.

Liposomes are the self-assembling lipidic nanoparticles consisting of a lipid-bilayer. These are novel carrier systems available in the marketplace for the treatment of cancer. A major obstacle in the successful treatment of cancer is the multidrug resistance (MDR) offered by cancerous cells. In this regard, two drugs, namely, resveratrol, and paclitaxel, were coencapsulated with a PEGylated liposome as a combinational therapy. The encapsulated liposome showed 50\% encapsulation efficiency and an improved in vitro cytotoxic activity against a drug-resistant MCF-7 cell line. Along with this property, it also demonstrated improved bioavailability and drug retention in tumor cells. When administered to mice, it effectively worked against drug-resistant tumors, with no prominent systemic toxicity. The study thus proposed that codelivery of resveratrol and paclitaxel in a nanocarrier system may present an enhanced therapeutic efficiency against MDR cancerous cells [149]. Another study was performed wherein PEGylated liposomes loaded with anastrozole were prepared by the film hydration method for the effective treatment of breast cancer. The liposomes were prepared using soyaphosphatidylcholine, cholesterol, and methoxy polyethylene glycol distearoyl ethanolamine. The optimized formulations were assessed for their activity by in vitro cell line studies on BT-549 and MCF-7 cell lines and for their in vivo behavior in Wistar rats. The area under the curve (AUC) showed a many-fold increase in the case of PEGylated liposomes, which substantiated that PEGylated liposomes could improve systemic circulation and deliver a sustained release of drugs for breast cancer therapy [150]. Recently, ruthenium(III)-complexes containing liposomes demonstrated promising results in treating different types of BC, including TNBC, by causing sustained cell death [151]. In another study, antibody-tethered liposomes loaded with docetaxel, a prodrug targeting Ephrin receptor A2, were developed, which showed reduced drug concentration in systemic circulation by achieving the required drug concentration at the tumor microenvironment in a sustained manner, thereby reducing systemic side effects [152]. Liposomes formulated by loading imiquimod R837, an immune adjuvant TLR7 agonist, and hematoporphyrin monomethyl ether, a sonosensitizer, showed promising tumor growth arrest and was also helpful in preventing metastasis to the lung [153]. The US FDA has approved formulations containing liposomes of which Doxil ${ }^{\circledR}$ (pegylated liposomal doxorubicin) is the first FDA-approved (1995) 'nanodrug' for the therapy of metastatic ovarian cancer and AIDS-related Kaposi's sarcoma. Table 8 lists the liposomal-based formulations that have been approved by the US FDA and are under clinical development. 
Table 8. List of liposome-based drug products approved by the US FDA and under clinical investigation.

\begin{tabular}{|c|c|c|c|c|}
\hline Product & Drug & Manufacturer & Indications & $\begin{array}{c}\text { US FDA Approved } \\
\text { Date/Clinical Trial Status }\end{array}$ \\
\hline Doxil (Caelyx) & $\begin{array}{l}\text { Pegylated } \\
\text { doxorubicin }\end{array}$ & $\begin{array}{l}\text { Orthobiotech, } \\
\text { Schering-Plough }\end{array}$ & Ovarian/breast cancer & November 1995 \\
\hline Myocet & $\begin{array}{c}\text { Liposome-encapsulated } \\
\text { Doxorubicin }\end{array}$ & $\begin{array}{l}\text { Elan/Sopherion } \\
\text { Therapeutics }\end{array}$ & Breast cancer & $\begin{array}{l}\text { 2000, Approved in } \\
\text { Europe and Canada }\end{array}$ \\
\hline LEP-ETU & Liposomal Paclitaxel & Neopharma & Ovarian/breast/lung cancers & Phase I/II \\
\hline EndoTAG-I & Paclitaxel & Medigene/SynCore Biotechnology & $\begin{array}{l}\text { Breast cancer/pancreatic } \\
\text { cancer }\end{array}$ & Phase II \\
\hline Genexal-PM & $\begin{array}{l}\text { Paclitaxel-loaded } \\
\text { polymeric micelle }\end{array}$ & Samyang & $\begin{array}{l}\text { Breast cancer/small } \\
\text { cell lung cancer }\end{array}$ & Marketed in Europe, Korea \\
\hline Nektar -102 & $\begin{array}{c}\text { Irinotecan, PEGylated } \\
\text { liposome }\end{array}$ & Nektar therapeutics & $\begin{array}{l}\text { Breast/colorectal } \\
\text { cancer }\end{array}$ & Phase III \\
\hline
\end{tabular}

Solid lipid nanoparticles (SLNs) are the colloidal systems consisting of a solid lipid matrix, which were developed as an alternative to traditional emulsions and liposomes. These carriers have also been exploited for plausible use in breast cancer therapy. Researchers have developed letrozole-loaded SLNs with folic acid surface modification, which presented significantly higher cytotoxicity when compared with the free drug in the MCF-7 cell line by caspase-3 dependent apoptosis [154]. Abd-Ellatef and coworkers formulated curcumin-loaded SLNs coated with chitosan and tested them on doxorubicin-resistant breast cancer cells. There was a 5 to 10 -fold increase in the toxicity and intracellular retention of doxorubicin in TNBC cells resistant to doxorubicin [155]. These SLN carriers were further improvised by mixing liquid lipid and solid lipid in a particular ratio to form a lipid core, which has helped in overcoming drug leaching during storage; these are named nanostructured lipid carriers (NLCs). These NLCs have several advantages over the conventional carriers in terms of prolonged half-life, increased permeability, biocompatibility, and improved storage stability. These NLCs have also been exploited for the loading of drugs for the treatment of breast cancer. In one such study, lapachone and doxorubicin were coloaded in NLCs and assessed for the treatment of MDR BC. In vitro studies on MCF-7 ADR cells showed increased uptake of doxorubicin when given in combination. In in vivo studies on MCF-7 ADR, tumor-bearing mice revealed enhanced efficacy when administered in combination, as compared to doxorubicin monotherapy [156]. Phytochemical resveratrol also showed improved efficiency when loaded into NLCs tethered with folic acid [157]. In another study, efforts were made to improve the targeting efficiency of paclitaxel and photosensitizers to tumor cells. A novel carrier containing paclitaxel, chlorin e6 conjugated with folic acid, was formulated to target tumor tissues. In vitro cell line studies on MDA-MB-231 cells showed an enhanced uptake that was substantiated by the in vivo studies on nude mice, which revealed that the combination of anticancer drugs and photodynamic therapy had an improved outcome in the reduction of tumor size [158]. In yet another study, the efficacy of NLCs loaded with epigallocatechin gallate and protamine sulfate, functioning as a stimuli-responsive agent to the presence of ATP, was evaluated for BC therapy. The results of these studies revealed promising outcomes in the treatment of BC [159].

\subsection{Dendrimers (DM)}

Dendrimers are highly branched macromolecules with a polymeric core, interior branches, and a functionalized exterior surface. They are multipurpose, changeable structures with a monodisperse size and can be easily loaded with different therapeutic agents. Dendrimer-modified magnetic NPs have shown an enhanced therapeutic value of chemotherapy. They have proved to be a useful source of magnetic resonance (MR) image contrast agents [160]. Researchers have prepared curcumin-loaded dendrimer-based ferric oxide nanoparticles coated with citric acid. These NPs were developed using polyamidoamine (PAMAM), a generation 5.0 dendrimer. To assess the antitumor activity of the prepared formulation, curcumin-alone and curcumin-loaded nanocarriers were compared by using a 3-(4,5-dimethylthiazol-2-yl)-2,5-diphenyltetrazolium bromide assay on MCF-7 cell lines. The results revealed that the dendrimer-modified NPs proved more effective against cancerous cells as it showed a slow and controlled release of drugs in the treatment of BC [161]. In another study, docetaxel-loaded dendrimers that were grafted with trastuzumab on the surface were synthesized. 
Trastuzumab-grafted DM showed higher internalization and antiproliferative effects on MDA-MB-453 than that of DM without trastuzumab grafting [162]. The plausible role of epidermal growth factor receptor (EGFR)-binding peptide-1 (EP-1) as a targeting agent against TNBC was assessed using poly(amidoamine) DM coupled with EP-1 and transactivating transcriptional cell-penetrating peptide-loaded with doxorubicin. The studies revealed that this DM acted as a dual functional drug carrier and showed a high antiproliferative effect on a TNBC MDA-MB-231 cell line when compared with free doxorubicin and DM without grafting [163]. Scientists have conjugated methotrexate with poly(amidoamine) DM, which showed two-times higher efficacy than that of plain methotrexate [164]. A study was conducted to test and demonstrate that the nanoscale system based on the Janus (a peptide) dendron drug conjugate can effectively act as a vehicle for the delivery of chemotherapeutic drugs for BC. The Janus dendron was fruitfully reformed with mPEG and PVGLIG-doxorubicin (DOX), through 2 steps, very effectively by cycloaddition (CuAAC) copper-catalyzed alkyne-azide click. The developed nanosystem showed significantly fewer side effects and higher efficiency, proving it to be a potent chemotherapeutic delivery vehicle for BC when compared to free DOX [165].

\subsection{Aptamer}

Aptamers are peptides or oligonucleotides that have the ability to bind to specific targets [166]. They have a unique pharmacokinetic profile, which makes their formulation difficult when compared to other proteins. Researchers are working on it and have come up with a new methodology to formulate a transducer on a gold surface, which provides a larger surface area to restrain the high quantity of the aptamer. The apta-sensor was deployed to detect the platelet-derived growth factor (PDGF) using square wave voltammetry (SWV) and cyclic voltammetry (CV) techniques. The proposed GNPs-cubic- $\alpha$-CD-Apt-Au electrode apta-sensor displayed excellent analytical performance for MCF-7 cell determination under optimized experimental conditions. The electrochemical apta-sensor could detect cancer-related targets with much higher efficiency in unprocessed human plasma samples [167]. Efforts were made to overcome drug resistance by developing liposomes loaded with doxorubicin-aptamer AS1411 (Ap-Dox). In vitro studies on MCF-7/ADR cells revealed that the liposome carrier tagged with aptamer was capable of getting bound to nucleolin and effectively caused cell death [168]. In another study, paclitaxel-loaded PLGA nanoparticles functionalized with PEG were developed, which were further conjugated with heparanase aptamer. In vitro studies on MDA-MB-231 cells revealed higher cell toxicity as compared to that of the nonfunctionalized carrier. Preclinical studies have shown a significant reduction in tumor volume compared to that of plain nanoparticles, suggesting that heparanase aptamer may be a promising target for TNBC drug delivery [169]. Wang and co-workers formulated an aptamer surface modified with the nanotags of surface-enhanced Raman scattering agents. These aptamers demonstrated precise imaging capability with high toxicity on irradiation with lasers, due to their photothermal property, in the MCF-7 cell-lines [170]. Mesoporous silica on top of iron nanoparticles loaded with doxorubicin (DOX) and tethered with mucin-aptamer on the surface demonstrated MRI ability and high cytotoxicity in mucin overexpressed BC cell lines [171].

\subsection{Inorganic Nanoparticles}

Of late, inorganic particles have been gaining widespread interest and have been widely explored in the diagnosis and treatment of cancer. They have advantages over organic nanoparticles in terms of their specific targeting ability and unique characteristics, which can be easily manipulated to target tumors [172]. There has been a clinical limitation of methotrexate (MTX) standalone treatment because of an extremely short plasma half-life. To combat this, a new system of drug delivery was proposed wherein an MTX-LDH (methotrexate-lactate dehydrogenase) nano-hybrid system was developed, which induced enhanced apoptosis when compared with free MTX. The annexin-V and propidium iodide dual bonding and tunnel investigation exhibited superior results and better targeting when investigated in mice bearing orthotropic human breast tumors, resulting in a greater reduction in 
tumor volume compared to standalone methotrexate after treatment of $2 \mathrm{~h}$ [173]. $\mathrm{Xu}$ and team studied the efficacy of $\mathrm{pH}$, glutathione, and hyaluronidase triple-responsive gold nanoparticles as a therapeutic approach in CD44 and HER2 overexpressed BC. In addition, the developed nanoparticles also had the properties of imaging-guided photodynamic therapy (PDT) and photothermal therapy. When conjugated with 5-aminolevulinic acid (ALA), Cy7.5, and anti-HER2 antibody onto hyaluronic acid (HA) moiety, the nanoparticles showed enhanced cellular uptake and efficient cell death when compared to individual therapy. The in vivo results showed the elimination of cancer cells entirely, with minimal side effects, which suggest that the developed carrier can be efficiently utilized for the treatment of BC [174]. In another study, redox-responsive nanogels, conjugated with hyaluronic acid loaded with doxorubicin, were fabricated for the treatment of cancer. Gold nanorods, conjugated with hyaluronic acid-cystamine as a crosslinker, were developed and found to release the drug in response to the presence of intracellular glutathione. Studies on MCF-7 cell lines revealed enhanced uptake, whereas MCF-7 ADR cells showed reduced uptake due to drug efflux. However, on near-infrared irradiation, the resistance of the MCF-7 ADR cells could be overcome [175]. The concept of siRNA, which has the ability to silence genes, has greater applicability in patients with BRCA1/BRCA2 mutations. siRNA alone may not help to treat BRCA1/BRCA2-positive BC. The study on BRCA1-expressed HeLa cells demonstrated increased sensitivity and apoptosis to proteasome inhibitors such as carfilzomib and bortezomib after treatment with siRNAs $[176,177]$. A study conducted by Shenda and co-workers showed promising results in the reversing/overcoming of trastuzumab and lapatinib resistance in 18HER2-positive cell lines, wherein they formulated mesoporous silica loaded with siRNA and tagged with trastuzumab. The study also showed that cell lines did not develop resistance to long-time siRNA treatment [178]. siRNA (of survivin and CDC20)-loaded polyplexes, formulated using methylcellulose, hyaluronic acid, dextran sulfate, and polyacrylic acid, showed increased antiproliferative and cell death in different cell lines such as MDA-MB-436, SUM149PT, MDA-MB-231, and MCF-7 [179]. Gao and co-workers synthesized polydopamine coated titanium nanoprobes containing chlorine e6 chelated with manganese (II) ion. These multifunctional NPs have shown a synergistic effect of photothermal/photodynamic properties and magnetic resonance imaging (MRI) in the BC mouse model [180]. Targeted image-guided therapy of HER2-positive BC was developed using a theranostic agent that consisted of bismuth sulfide mesoporous silica NP core shells. The formulating procedure included chemical encapsulation of mesoporous silica with polyvinylpyrrolidone decorated rod-like bismuth sulfide mesoporous silica. The mesoporous layer consisted of doxorubicin. The NPs formed were chemically conjugated with a monoclonal antibody (trastuzumab), giving rise to trastuzumab bismuth sulfide mesoporous silica nanoparticles (Tam-Bi2S3@mPS). The formulation demonstrated improved drug loading capacity, biocompatibility, and specific and active cancer cell targeting, with enhanced accumulation inside the cells. They served two purposes: First, as an exceptional contrast development probe owing to the presence of bismuth for computer tomography for deep inside tumor tissue imaging. Secondly, it was observed that these NPs effectively destroyed tumors and inhibited metastasis by synergistic chemotherapy (Figure 5) [181].

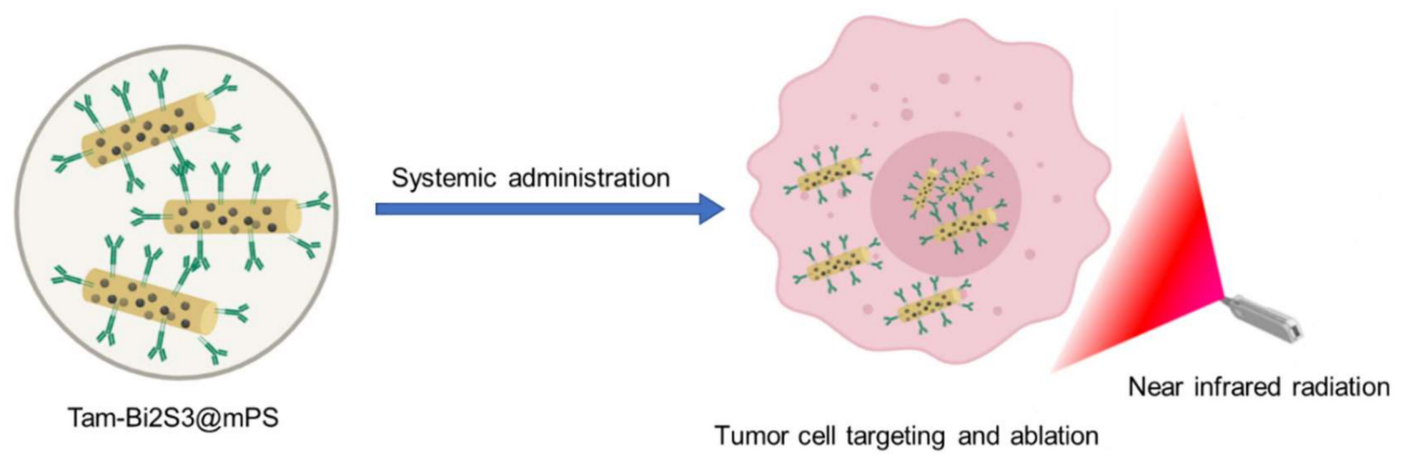

Figure 5. Diagrammatic presentation of the targeted Tam-Bi2S3@mPS theranostic nanoplatform. 


\subsection{Carbon Nanotubes (CNTs)}

Aromatic hydrocarbon rings involved in the formation of carbon cylinders are known as carbon nanotubes. The solubility issues associated with its formulation can be resolved by linking it to proteins and peptides, which are water-soluble ligands. Therapeutic agents are linked to these water-soluble ligands to improve their targeted action when compared to the pure drug alone. In a study, the restraint of currently available treatments for BC was explained by cancer stem cells (CSCs), which play a crucial role in carcinoma instigation, advancement, reappearance, and metastasis. Thus, carbon nanotubes have emerged as a potential field for treating BC. Single-walled carbon nanotube (SWCNT) biocompatible multimodality nano samples were prepared, and the therapeutic efficacy and biodistribution of the CD44 antibody combined with SWCNTs were examined using different methods such as magnetic resonance imaging (MRI) and computed tomography for single-photon emissions. SWCNT quantification was performed by sensitively calculating iron content in sorted CSC populations, adopting inductively combined plasma-mass spectrometry, and the study established the improved targeting of formulated nanotubes. Immunohistochemistry analysis was performed, which showed enhanced localization of nanotubes in areas that had abundant CD44 receptors. These data provided inspiring outcomes effectively aimed at breast CSCs [182]. Researchers have conjugated CNTs with PEG and $\beta$-estradiol and loaded with lobaplastin. $\beta$-estradiol, being the estrogen receptor agonist, helps in targeting the estrogen receptor, and PEG helps in enhancing systemic circulation. The results revealed that the adverse effect on vital organs like the liver, heart, and kidneys was negligible, and the formulation exhibited sustained-release on the mice-BC model [183]. Singh and co-workers formulated multiwalled CNTs conjugated with thiamine and riboflavin loaded with paclitaxel, which showed promising results on MCF-7 BC cell lines [184].

\subsection{Nanoshells (NSs)}

Nanoshells (NSs) are optically active NPs, which, when injected systemically, mount up within the cancerous cells due to the stimuli-responsive enhanced permeability and retention (EPR) effect. They induce photothermal death of the tumor cells once irradiated with the near-infrared optical device [185]. Programmed mesoporous nanoshells capped with silica gold nanorods and coated with nano-selenium layer nanoparticles were formulated. These NPs behaved as multifunctional nanoplatforms to include materials with explicit chemotherapeutic activity, which contribute to enhancing antitumor value in MDR BC. The formulated NPs, along with encapsulated doxorubicin, showed sufficient accumulation in tumor cells. The release of the drug was remotely operated by mild near-infrared irradiation. The formulation improved the cell-killing effect by inducing apoptosis. In addition to this, it also prevented the growth of tumor cells by the arrest of the cell cycle and initiated apoptosis by suppressing Src/FAK/AKT signaling pathways. The combination of selenium photothermal-chemotherapy significantly suppressed the growth of the tumor and slowed down its advancement. Visible signs of organ impairment or toxicity were not detected, which was further confirmed by hematology and biochemical analysis. Therefore, the prepared formulation showed the possibility of treating metastatic BC with less or no significant adverse effects [186]. Gold NSs tagged with trastuzumab were administered to trastuzumab-resistant HER2-tumor xenografts. NSs showed a time-dependent increase in accumulation in the tumor tissue after administration of NSs intravenously, followed by irradiation with the femtosecond-pulsed laser. The results revealed significant inhibition of tumor proliferation. This study concluded that photothermal therapy and gold NS-tagged with trastuzumab may be used to overcome trastuzumab resistance [187]. In a similar study, plasmonic NSs made up of polycaprolactone and gold were synthesized, which showed effective/significant localized photo-thermolysis in different cell lines irrespective of receptor makeup. These NSs were capable of producing standalone and considerable eradication of cancer cells without chemotherapeutic agents [188]. 


\subsection{Viral Nanoparticles}

Nucleic acid/drug loaded into the empty virus capsid once the virulence is removed from its genetic material is referred to as a viral nanoparticle. This transporter system has various advantages gained from the structural arrangement of NPs and naturally responsive capsid surfaces. NPs utilizing nonpathogenic viruses (plant or synthetic) are emerging as an innovative drug delivery strategy as far as nanotechnology is concerned. Plant viruses, when formulated as viral NPs, showed clear advantages over any synthetic ones, the reason being their biocompatible and biodegradable nature. They also have an added benefit of being inexpensive when compared to synthetic nanoparticles. Virus $X$, extracted from potato, was used as a carrier for chemotherapeutic drug herceptin. Herceptin showed a therapeutic effect against HER2-positive BC cells in cancer patients. Researchers have conjoined potato virus $X$ along with herceptin (trastuzumab), a monoclonal antibody for targeting HER2-positive BC cells. The bioconjugation was carried out in two steps in the presence of EDC/sulfo-N-hydroxysuccinimide (sulfo-NHS) [189]. Conjugation efficiency was examined by various methods such as sodium dodecyl sulfate-polyacrylamide gel electrophoresis (SDS-PAGE), Western blot, and ELISA. These methods confirmed the formation of a protein band formed as a result of conjugation. The bioconjugate could induce apoptosis in SKOV-3 and SK-BR-3 cells (HER2-positive cell lines). The flow cytometry assay measured apoptosis caused by the bioconjugate and compared it with herceptin alone. From the result obtained, it was concluded that potato virus $X$-herceptin conjugate had enabled herceptin to become a more potential anticancer drug for treating breast cancer [190].

Tobacco mosaic virus (TMV) is a hollow cylindrical nanotube which is converted into spherical nanoparticles of around $50 \mathrm{~nm}$ by a heat-transformation method. These spherical TMVs were loaded with doxorubicin, which showed similar antiproliferative effects as that of free doxorubicin on MDA-MB-231 and MCF-7 [191].

\section{Artificial Intelligence in Personalized BC Therapy}

The development of artificial intelligence (AI) in healthcare, especially in the field of cancer, has paved the way for the implementation of personalized medicine. As BC is cancer with complex heterogeneity, personalized medicine based on the genetic and molecular data can be an alternative for its effective treatment. The breakthrough research was put forth by a group of scientists at the Institute of Cancer Research used AI to identify different subtypes of BC where patients responded differently to standard therapy based on the critical differences among the cancer types. Research is currently underway to identify the differences in the genetic and molecular patterns of the BC patients and to include them in clinical trials to implement personalized therapy as a standard treatment. AI was able to identify the cancer subtypes based on the vast amount of data available on the genetic and molecular makeup of cancer, especially luminal cancer, along with patient survival data [192]. The difference in the markers identified in the patients using AI was able to suggest possible treatment implications. This unique advantage of $\mathrm{AI}$ in personalizing treatments based on genetic sequences, can be explored for enhanced efficacy in BC patients, including those with MDR BC. AI can also be successfully interfaced with nanomedicine, specifically in the optimization of combination drug therapy based on the stratification of patients as per the $\mathrm{BC}$ type and to maintain the drug levels at the target site [193]. In addition, AI may also aid in the selection of materials for the preparation of nanocarriers based on their interaction with drug targets, biological fluids, and cell membranes, which ultimately affect therapeutic efficacy [194]. However, challenges such as data integrity, a huge amount of data and translation of this data into knowledge, ethical consideration, and regulatory approvals lay back the clinical translation of AI [195].

\section{Toxicity Associated with Advanced Nano-Based Therapy of BC}

NPs are available currently, even though considered to be less toxic and more effective drug carriers, they are associated with a certain degree of toxicity (Figure 6). It is reported that after the administration 
of NPs, there is an increase in the phagocytic cell count and a reduction in the immunological defences of the body. NPs cause cytotoxicity by stimulating the release of pro-inflammatory factors [196]. They also have the ability to accumulate around the protein, depending on their shape, particle size, curvature, and free energy surface charge, which may cause crosslinking and unfolding of proteins, and lead to a loss of enzymatic activity and cell death [197].

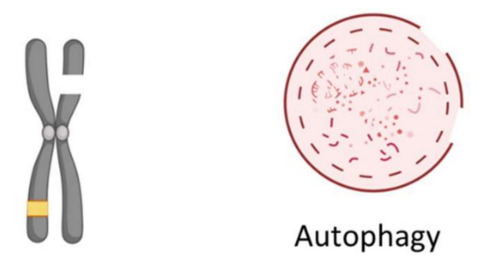

Chromosomal aberrations

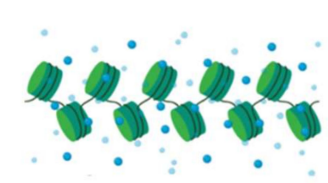

Histone modifications

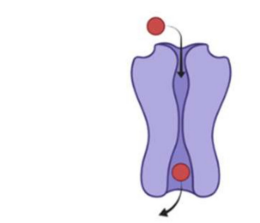

Ion exchange disorder
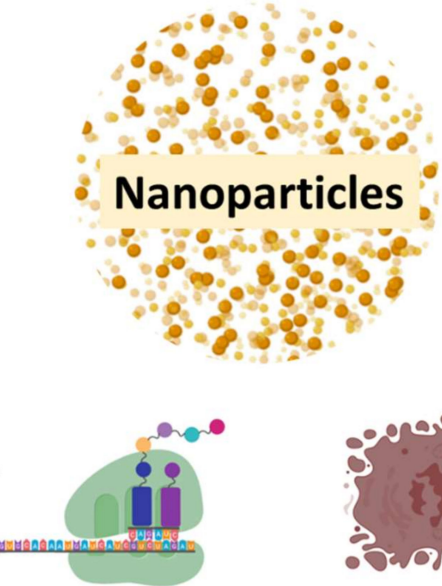

Signaling pathway alteration

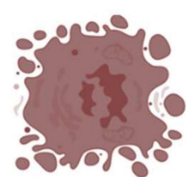

Oxidative stress

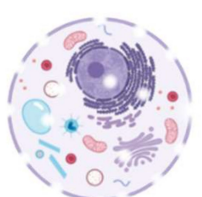

Cell membrane damage and increase in permeability

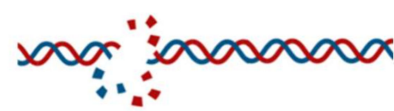

DNA damage, mutations

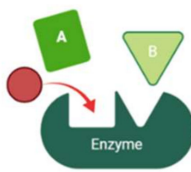

Enzyme failure

Figure 6. Toxicity associated with nanoparticles.

Immune checkpoint inhibitors have shown to cause autoimmune responses and may cause psoriasis, uveitis, inflammatory colitis, and maculopapular rash. The adverse effect of a combination of immunotherapy is much more complicated and difficult to handle [198-200].

It was observed that after the administration of gene-therapy doses, the immune system of the patient might react and result in a drop in blood pressure, fever, headache, nausea, and vomiting. As gene-therapy is a comparatively newer therapy, the long-term side effects are yet to be established [201].

\section{Summary and Future Perspective}

Breast cancer is a complex system with enormous heterogenicity within itself. Conventional therapy lacks specificity to the tumor tissue, causing intolerable side effects and leading to the development of resistance. Over the years, there has been an improved clinical outcome owing to the latest developments in both immunotherapy and nanotechnology. For HR-positive BC, anti-estrogens, along with aromatase inhibitors, have proven to be a powerful therapy. MAbs against HER2-receptors, with tagging of chemotherapeutic agents (ADC), has shown drastic improvement in the therapeutic outcome. TNBC, being the most aggressive and challenging to treat, can be effectively treated with immune checkpoint inhibitors along with chemotherapeutic agents. PARP inhibitors and drugs targeting the RANK/RANKL system are the latest drugs that have added on to the list of BC drugs. In the past few years, extensive research has been undertaken to overcome resistance to $B C$ therapy and improve its prognosis. NPs loaded with chemotherapeutic agents, along with surface modifications, have been extensively studied and have proven to be an effective treatment strategy with minimal systemic side effects. NPs such as theranostics, which have the combined potential of both 
diagnosing and treating, can be tailored as a personalized medicine for BC. The major challenge faced by researchers is the identification of suitable biomarkers that are responsible for the development of resistance and response. The development of resistance to current therapy has become a cause of concern, limiting the effectiveness of treatments. One of the breakthrough strategies proven to reverse resistance is the use of multimodal therapy. Nevertheless, the development of resistance and intolerance to current therapy needs to be addressed to improve the overall therapeutic outcome and morbidity in $\mathrm{BC}$ patients.

Many new agents and new combination strategies are under clinical investigation, and if successful, could be translated clinically, which will be a ray of hope for treating BC effectively. In addition, $\mathrm{BC}$ therapy can be further revolutionized by adopting a personalized treatment strategy based on the biological and molecular specification of individual patients so that the right dose and regimen for treatment can be optimized. Treatment strategies can be designed with the aid of gene profiling to identify genetic biomarkers. However, the major challenge lies in the effective clinical translation of this approach due to the complexities involved in regulatory approvals and data integrity.

\section{Conclusions}

A gradual but continuous decrease in the mortality rate of BC patients has been observed in the past few decades. The prime reason behind this progress is the advancement in the technologies and approaches adopted. Targeted drug delivery systems and multimodal therapy have proven to be more efficacious in treating BC with minimal systemic toxicity. Immunotherapy is well tolerated when compared to chemotherapy and has shown a relatively lower adverse effect. There is a need for a more profound understanding of molecular mechanisms and biomarkers involved in BC development and the mechanism by which cancer cells develop resistance. Stratification of patients, according to specific biomarkers, plays a crucial role in the effective treatment of $B C$, whereby the symptoms of patients can be ameliorated, thereby improving the quality of life of patients. Treatment strategies/approaches should be tailored as per individuals for effective treatment.

Funding: Authors are thankful to the Science and Engineering Research Board, Dept. of Science and Technology, New Delhi, India (Ref. No. EMR/2016/007006) for the research funding.

Conflicts of Interest: The authors declare that there is no conflict of interest in publishing this article.

\section{References}

1. Siegel, R.L.; Miller, K.D.; Jemal, A. Cancer statistics, 2019 (US statistics). CA Cancer J. Clin. 2019, 69, 7-34. [CrossRef] [PubMed]

2. Study Forecasts New Breast Cancer Cases by 2030-National Cancer Institute. Available online: https: //www.cancer.gov/news-events/cancer-currents-blog/2015/breast-forecast (accessed on 17 March 2020).

3. Polyak, K. Heterogeneity in breast cancer Find the latest version: Review series introduction Heterogeneity in breast cancer. J. Clin. Investig. 2011, 121, 3786-3788. [CrossRef] [PubMed]

4. Tong, C.W.S.; Wu, M.; Cho, W.C.S.; To, K.K.W. Recent Advances in the Treatment of Breast Cancer. Front. Oncol. 2018, 8, 227. [CrossRef] [PubMed]

5. Haque, R.; Ahmed, S.A.; Inzhakova, G.; Shi, J.; Avila, C.; Polikoff, J.; Bernstein, L.; Enger, S.M.; Press, M.F. Impact of breast cancer subtypes and treatment on survival: An analysis spanning two decades. Cancer Epidemiol. Biomark. Prev. 2012, 21, 1848-1855. [CrossRef] [PubMed]

6. Breast Cancer|Breast Cancer Information \& Overview. Available online: https://www.cancer.org/cancer/ breast-cancer.html (accessed on 17 March 2020).

7. Day, C.M.; Hickey, S.M.; Song, Y.; Plush, S.E.; Garg, S. Novel tamoxifen nanoformulations for improving breast cancer treatment: Old wine in new bottles. Molecules 2020, 25, 1182. [CrossRef]

8. Reinert, T.; Barrios, C.H. Optimal management of hormone receptor positive metastatic breast cancer in 2016. Ther. Adv. Med. Oncol. 2015, 7, 304-320. [CrossRef]

9. Haque, M.M.; Desai, K.V. Pathways to Endocrine Therapy Resistance in Breast Cancer. Front. Endocrinol. (Lausanne) 2019, 10, 573. [CrossRef] 
10. Szostakowska, M.; Trębińska-Stryjewska, A.; Grzybowska, E.A.; Fabisiewicz, A. Resistance to endocrine therapy in breast cancer: Molecular mechanisms and future goals. Breast Cancer Res. Treat. 2019, 173, 489-497. [CrossRef]

11. Liedtke, C.; Mazouni, C.; Hess, K.R.; André, F.; Tordai, A.; Mejia, J.A.; Symmans, W.F.; Gonzalez-Angulo, A.M.; Hennessy, B.; Green, M.; et al. Response to neoadjuvant therapy and long-term survival in patients with triple-negative breast cancer. J. Clin. Oncol. 2008, 26, 1275-1281. [CrossRef]

12. Berrada, N.; Delaloge, S.; André, F. Treatment of triple-negative metastatic breast cancer: Toward individualized targeted treatments or chemosensitization? Ann. Oncol. 2010, 21, vii30-vii35. [CrossRef]

13. Shah, A.N.; Cristofanilli, M. The Growing Role of CDK4/6 Inhibitors in Treating Hormone Receptor-Positive Advanced Breast Cancer. Curr. Treat. Options Oncol. 2017, 18, 6. [CrossRef] [PubMed]

14. Xu, H.; Yu, S.; Liu, Q.; Yuan, X.; Mani, S.; Pestell, R.G.; Wu, K. Recent advances of highly selective CDK4/6 inhibitors in breast cancer. J. Hematol. Oncol. 2017, 10, 97. [CrossRef] [PubMed]

15. Gelbert, L.M.; Cai, S.; Lin, X.; Sanchez-Martinez, C.; del Prado, M.; Lallena, M.J.; Torres, R.; Ajamie, R.T.; Wishart, G.N.; Flack, R.S.; et al. Preclinical characterization of the CDK4/6 inhibitor LY2835219: In-vivo cell cycle-dependent/independent anti-tumor activities alone/in combination with gemcitabine. Investig. New Drugs 2014, 32, 825-837. [CrossRef] [PubMed]

16. Kwapisz, D. Cyclin-dependent kinase $4 / 6$ inhibitors in breast cancer: Palbociclib, ribociclib, and abemaciclib. Breast Cancer Res. Treat. 2017, 166, 41-54. [CrossRef]

17. FDA Expands Ribociclib Indication in HR-Positive, HER2-Negative Advanced or Metastatic Breast Cancer|FDA. Available online: https:/www.fda.gov/drugs/resources-information-approved-drugs/fdaexpands-ribociclib-indication-hr-positive-her2-negative-advanced-or-metastatic-breast-cancer (accessed on 6 October 2019).

18. FDA Approves Abemaciclib as Initial Therapy for HR-Positive, HER2-Negative Metastatic Breast Cancer|FDA. Available online: https://www.fda.gov/drugs/resources-information-approved-drugs/fdaapproves-abemaciclib-initial-therapy-hr-positive-her2-negative-metastatic-breast-cancer (accessed on 6 October 2019).

19. Palbociclib (IBRANCE)|FDA. Available online: https://www.fda.gov/drugs/resources-information-approveddrugs/palbociclib-ibrance (accessed on 6 October 2019).

20. Engelman, J.A.; Luo, J.; Cantley, L.C. The evolution of phosphatidylinositol 3-kinases as regulators of growth and metabolism. Nat. Rev. Genet. 2006, 7, 606-619. [CrossRef]

21. Martini, M.; De Santis, M.C.; Braccini, L.; Gulluni, F.; Hirsch, E. PI3K/AKT signaling pathway and cancer: An updated review. Ann. Med. 2014, 46, 372-383. [CrossRef]

22. Fruman, D.A.; Chiu, H.; Hopkins, B.D.; Bagrodia, S.; Cantley, L.C.; Abraham, R.T. The PI3K Pathway in Human Disease. Cell 2017, 170, 605-635. [CrossRef]

23. Slomovitz, B.M.; Coleman, R.L. The PI3K/AKT/mTOR Pathway as a Therapeutic Target in Endometrial Cancer. Clin. Cancer Res. 2012, 18, 5856-5864. [CrossRef]

24. DiNitto, J.P.; Cronin, T.C.; Lambright, D.G. Membrane recognition and targeting by lipid-binding domains. Sci. STKE 2003, 2003, re16. [CrossRef]

25. Sarbassov, D.D.; Guertin, D.A.; Ali, S.M.; Sabatini, D.M. Phosphorylation and regulation of Akt/PKB by the rictor-mTOR complex. Science 2005, 307, 1098-1101. [CrossRef]

26. Polivka, J.; Janku, F. Molecular targets for cancer therapy in the PI3K/AKT/mTOR pathway. Pharmacol. Ther. 2014, 142, 164-175. [CrossRef] [PubMed]

27. Dowling, R.J.O.; Zakikhani, M.; Fantus, I.G.; Pollak, M.; Sonenberg, N. Metformin inhibits mammalian target of rapamycin-dependent translation initiation in breast cancer cells. Cancer Res. 2007, 67, 10804-10812. [CrossRef] [PubMed]

28. Barra, F.; Evangelisti, G.; Ferro Desideri, L.; Di Domenico, S.; Ferraioli, D.; Vellone, V.G.; De Cian, F.; Ferrero, S. Investigational PI3K/AKT/mTOR inhibitors in development for endometrial cancer. Expert Opin. Investig. Drugs 2019, 28, 131-142. [CrossRef] [PubMed]

29. Brufsky, A.M.; Dickler, M.N. Estrogen Receptor-Positive Breast Cancer: Exploiting Signaling Pathways Implicated in Endocrine Resistance. Oncologist 2018, 23, 528-539. [CrossRef] [PubMed]

30. Brufsky, A.M. Long-term management of patients with hormone receptor-positive metastatic breast cancer: Concepts for sequential and combination endocrine-based therapies. Cancer Treat. Rev. 2017, 59, $22-32$. [CrossRef] 
31. Tolaney, S.; Burris, H.; Gartner, E.; Mayer, I.A.; Saura, C.; Maurer, M.; Ciruelos, E.; Garcia, A.A.; Campana, F.; $\mathrm{Wu}, \mathrm{B}$; ; et al. Phase I/II study of pilaralisib (SAR245408) in combination with trastuzumab or trastuzumab plus paclitaxel in trastuzumab-refractory HER2-positive metastatic breast cancer. Breast Cancer Res. Treat. 2015, 149, 151-161. [CrossRef]

32. Saura, C.; Bendell, J.; Jerusalem, G.; Su, S.; Ru, Q.; De Buck, S.; Mills, D.; Ruquet, S.; Bosch, A.; Urruticoechea, A.; et al. Phase Ib Study of Buparlisib plus Trastuzumab in Patients with HER2-Positive Advanced or Metastatic Breast Cancer That Has Progressed on Trastuzumab-Based Therapy. Clin. Cancer Res. 2014, 20, 1935-1945. [CrossRef]

33. Guerin, M.; Rezai, K.; Isambert, N.; Campone, M.; Autret, A.; Pakradouni, J.; Provansal, M.; Camerlo, J.; Sabatier, R.; Bertucci, F.; et al. PIKHER2: A phase IB study evaluating buparlisib in combination with lapatinib in trastuzumab-resistant HER2-positive advanced breast cancer. Eur. J. Cancer 2017, 86, 28-36. [CrossRef]

34. Palmieri, C.; Stein, R.C.; Liu, X.; Hudson, E.; Nicholas, H.; Sasano, H.; Guestini, F.; Holcombe, C. CLINICAL TRIAL IRIS study: A phase II study of the steroid sulfatase inhibitor Irosustat when added to an aromatase inhibitor in ER-positive breast cancer patients. Breast Cancer Res. Treat. 2017, 165, 343-353. [CrossRef] [PubMed]

35. Morozkina, S.N.; Shavva, G.A. Estrone Sulfatase Inhibitors as New Anticancer Agents. In Chemistry and Biological Activity of Steroids; IntechOpen: London, UK, 2019.

36. Wisinski, K.B.; Tevaarwerk, A.J.; Burkard, M.E.; Rampurwala, M.; Eickhoff, J.; Bell, M.C.; Kolesar, J.M.; Flynn, C.; Liu, G. Phase I study of an AKT inhibitor (MK-2206) combined with lapatinib in adult solid tumors followed by dose expansion in advanced HER2 + breast cancer. Clin. Cancer Res. 2016, 22, 2659-2667. [CrossRef]

37. Acevedo-Gadea, C.; Hatzis, C.; Chung, G.; Fishbach, N.; Lezon-Geyda, K.; Zelterman, D.; DiGiovanna, M.P.; Harris, L.; Abu-Khalaf, M.M. Sirolimus and trastuzumab combination therapy for HER2-positive metastatic breast cancer after progression on prior trastuzumab therapy. Breast Cancer Res. Treat. 2015, 150, 157-167. [CrossRef] [PubMed]

38. Her, W.; Metastatic, T.; Seiler, M.; Ray-coquard, I.; Melichar, B.; Yardley, D.A.; Wang, R.X.; Dodion, P.F.; Lee, M.A. Oral Ridaforolimus Plus Trastuzumab for Patients Breast Cancer. Clin. Breast Cancer 2015, 15, 60-65.

39. Mukai, H.; Saeki, T.; Aogi, K.; Naito, Y.; Matsubara, N.; Shigekawa, T.; Ueda, S.; Takashima, S.; Hara, F.; Yamashita, T.; et al. Patritumab plus trastuzumab and paclitaxel in human epidermal growth factor receptor 2-overexpressing metastatic breast cancer. Cancer Sci. 2016, 107, 1465-1470. [CrossRef] [PubMed]

40. Bahrami, A.; Khazaei, M.; Shahidsales, S.; Hassanian, S.M.; Hasanzadeh, M.; Maftouh, M.; Ferns, G.A.; Avan, A. The Therapeutic Potential of PI3K/Akt/mTOR Inhibitors in Breast Cancer: Rational and Progress. J. Cell. Biochem. 2018, 119, 213-222. [CrossRef] [PubMed]

41. Hudis, C.A. Trastuzumab-Mechanism of Action and Use in Clinical Practice. N. Engl. J. Med. 2007, 357, 39-51. [CrossRef] [PubMed]

42. Mitri, Z.; Constantine, T.; O'Regan, R. The HER2 Receptor in Breast Cancer: Pathophysiology, Clinical Use, and New Advances in Therapy. Chemother. Res. Pract. 2012, 2012, 743193. [CrossRef]

43. Nordstrom, J.L.; Gorlatov, S.; Zhang, W.; Yang, Y.; Huang, L.; Burke, S.; Li, H.; Ciccarone, V.; Zhang, T.; Stavenhagen, J.; et al. Anti-tumor activity and toxicokinetics analysis of MGAH22, an anti-HER2 monoclonal antibody with enhanced Fc $\gamma$ receptor binding properties. Breast Cancer Res. 2011, 13, R123. [CrossRef]

44. Bang, Y.J.; Giaccone, G.; Im, S.A.; Oh, D.Y.; Bauer, T.M.; Nordstrom, J.L.; Li, H.; Chichili, G.R.; Moore, P.A.; Hong, S.; et al. First-in-human Phase 1 study of margetuximab (MGAH22), an Fc-modified chimeric monoclonal antibody, in patients with HER2-positive advanced solid tumors. Ann. Oncol. 2017, 28, mdx002. [CrossRef]

45. Pento, J.T. Monoclonal Antibodies for the Treatment of Cancer. Anticancer Res. 2017, 37, 5935-5939.

46. Chan, A.; Delaloge, S.; Holmes, F.A.; Moy, B.; Iwata, H.; Harvey, V.J.; Robert, N.J.; Silovski, T.; Gokmen, E.; von Minckwitz, G.; et al. Neratinib after trastuzumab-based adjuvant therapy in patients with HER2-positive breast cancer (ExteNET): A multicentre, randomised, double-blind, placebo-controlled, phase 3 trial. Lancet Oncol. 2016, 17, 367-377. [CrossRef]

47. Dhillon, S. Neratinib in Early-Stage Breast Cancer: A Profile of Its Use in the EU. Clin. Drug Investig. 2019, 39, 221-229. [CrossRef] [PubMed] 
48. FDA Approves Neratinib for Metastatic HER2-Positive Breast Cancer|FDA. Available online: https://www.fda.gov/drugs/resources-information-approved-drugs/fda-approves-neratinib-metastaticher2-positive-breast-cancer (accessed on 17 March 2020).

49. Ma, F.; Li, Q.; Chen, S.; Zhu, W.; Fan, Y.; Wang, J.; Luo, Y.; Xing, P.; Lan, B.; Li, M.; et al. Phase I study and biomarker analysis of pyrotinib, a novel irreversible Pan-ERBB receptor tyrosine kinase inhibitor, in patients with human epidermal growth factor receptor 2-positive metastatic breast cancer. J. Clin. Oncol. 2017, 35, 3105-3112. [CrossRef] [PubMed]

50. Park, Y.H.; Lee, K.-H.; Sohn, J.H.; Lee, K.S.; Jung, K.H.; Kim, J.-H.; Lee, K.H.; Ahn, J.S.; Kim, T.-Y.; Kim, G.M.; et al. A phase II trial of the pan-HER inhibitor poziotinib, in patients with HER2-positive metastatic breast cancer who had received at least two prior HER2-directed regimens: Results of the NOV120101-203 trial. Int. J. Cancer 2018, 143, 3240-3247. [CrossRef] [PubMed]

51. Xu, B.; Ma, F.; Ouyang, Q.; Li, W.; Jiang, Z.; Tong, Z.; Liu, Y.; Li, H.; Yu, S.; Feng, J.; et al. Abstract PD3-08: A randomized phase II trial of pyrotinib plus capecitabine versus lapatinib plus capecitabine in patients with HER2-positive metastatic breast cancer previously treated with taxanes, anthracyclines and/or trastuzumab. Proc. Poster Discuss. Abstr. Am. Assoc. Cancer Res. 2018, 78, PD3-08.

52. Moulder, S.L.; Borges, V.F.; Baetz, T.; Mcspadden, T.; Fernetich, G.; Murthy, R.K.; Chavira, R.; Guthrie, K.; Barrett, E.; Chia, S.K. Phase I Study of ONT-380, a HER2 Inhibitor, in Patients with HER2 + -Advanced Solid Tumors, with an Expansion Cohort in HER2 ${ }^{+}$Metastatic Breast Cancer (MBC). Clin. Cancer Res. 2017, 23, 3529-3536. [CrossRef]

53. Anders, C.; Murthy, R.; Hamilton, E.; Borges, V.; Cameron, D.; Carey, L.; Müller, V.; Curigliano, G.; Gelmon, K.; Hortobagyi, G.; et al. Abstract CT055: A randomized, double-blinded, controlled study of tucatinib (ONT-380) vs. placebo in combination with capecitabine $(\mathrm{C})$ and trastuzumab $(\mathrm{Tz})$ in patients with pretreated HER2+ unresectable locally advanced or metastatic breast carcinoma (MBC) (HER2CLIMB). Proc. Clin. Trials Am. Assoc. Cancer Res. 2017, 77, CT055.

54. Tolcher, A.W. Antibody drug conjugates: Lessons from 20 years of clinical experience. Ann. Oncol. 2016, 27, 2168-2172. [CrossRef]

55. McCombs, J.R.; Owen, S.C. Antibody Drug Conjugates: Design and Selection of Linker, Payload and Conjugation Chemistry. AAPS J. 2015, 17, 339-351. [CrossRef]

56. Iwata, H.; Tamura, K.; Doi, T.; Tsurutani, J.; Modi, S.; Park, H.; Krop, I.E.; Sagara, Y.; Redfern, C.H.; Murthy, R.K.; et al. Trastuzumab deruxtecan (DS-8201a) in subjects with HER2-expressing solid tumors: Long-term results of a large phase 1 study with multiple expansion cohorts. J. Clin. Oncol. 2018, 36, 2501. [CrossRef]

57. Tamura, K.; Tsurutani, J.; Takahashi, S.; Iwata, H.; Krop, I.E.; Redfern, C.; Sagara, Y.; Doi, T.; Park, H.; Murthy, R.K.; et al. Trastuzumab deruxtecan (DS-8201a)in patients with advanced HER2-positive breast cancer previously treated with trastuzumab emtansine: A dose-expansion, phase 1 study. Lancet Oncol. 2019, 20, 816-826. [CrossRef]

58. Van der Lee, M.M.C.; Groothuis, P.G.; Ubink, R.; van der Vleuten, M.A.J.; van Achterberg, T.A.; Loosveld, E.M.; Damming, D.; Jacobs, D.C.H.; Rouwette, M.; Egging, D.F.; et al. The Preclinical Profile of the Duocarmycin-Based HER2-Targeting ADC SYD985 Predicts for Clinical Benefit in Low HER2-Expressing Breast Cancers. Mol. Cancer Ther. 2015, 14, 692-703. [CrossRef] [PubMed]

59. Menderes, G.; Bonazzoli, E.; Bellone, S.; Black, J.; Altwerger, G.; Masserdotti, A.; Pettinella, F.; Zammataro, L.; Buza, N.; Hui, P.; et al. SYD985, a novel duocarmycin-based HER2-targeting antibody-drug conjugate, shows promising antitumor activity in epithelial ovarian carcinoma with HER2/Neu expression. Gynecol. Oncol. 2017, 146, 179-186. [CrossRef] [PubMed]

60. Hamilton, E.P.; Barve, M.A.; Bardia, A.; Beeram, M.; Bendell, J.C.; Mosher, R.; Hailman, E.; Bergstrom, D.A.; Burris, H.A.; Soliman, H.H. Phase 1 dose escalation of XMT-1522, a novel HER2-targeting antibody-drug conjugate (ADC), in patients (pts) with HER2-expressing breast, lung and gastric tumors. J. Clin. Oncol. 2018, 36, 2546. [CrossRef]

61. Wang, J.; Xu, B.; Wang, W.; Fang, J. An open-label, dose-escalation phase I study to evaluate RC48-ADC, a novel antibody-drug conjugate, in patients with HER2-positive metastatic breast cancer. J. Clin. Oncol. 2018, 36, 1030. [CrossRef] 
62. Pegram, M.; Hamilton, E.; Tan, A.R.; Storniolo, A.M.; Elgeioushi, N.; Marshall, S.; Abdullah, S.; Patel, M. 47OPhase 1 study of bispecific HER2 antibody-drug conjugate MEDI4276 in patients with advanced HER2-positive breast or gastric cancer. Ann. Oncol. 2018, 29. [CrossRef]

63. Zizzari, I.G.; Veglia, F.; Taurino, F.; Rahimi, H.; Quaglino, E.; Belleudi, F.; Riccardo, F.; Antonilli, M.; Napoletano, C.; Bellati, F.; et al. HER2-based recombinant immunogen to target DCs through Fc $\gamma$ Rs for cancer immunotherapy. J. Mol. Med. 2011, 89, 1231-1240. [CrossRef]

64. Liu, L.; Wang, Y.; Miao, L.; Liu, Q.; Musetti, S.; Li, J.; Huang, L. Combination Immunotherapy of MUC1 mRNA Nano-vaccine and CTLA-4 Blockade Effectively Inhibits Growth of Triple Negative Breast Cancer. Mol. Ther. 2018, 26, 45-55. [CrossRef]

65. Narod, S.A.; Salmena, L. BRCA1 and BRCA2 mutations and breast cancer. Discov. Med. 2011, 12, 445-453.

66. BRCA: The Breast Cancer Gene-National Breast Cancer Foundation. Available online: https://www. nationalbreastcancer.org/what-is-brca (accessed on 7 October 2019).

67. Paul, A.; Paul, S. The breast cancer susceptibility genes (BRCA) in breast and ovarian cancers. Front. Biosci. (Landmark Ed.) 2014, 19, 605-618. [CrossRef]

68. Chen, H.; Wu, J.; Zhang, Z.; Tang, Y.; Li, X.; Liu, S.; Cao, S.; Li, X. Association between BRCA status and triple-negative breast cancer: A meta-analysis. Front. Pharmacol. 2018, 9, 909. [CrossRef]

69. Robson, M.; Im, S.-A.; Senkus, E.; Xu, B.; Domchek, S.M.; Masuda, N.; Delaloge, S.; Li, W.; Tung, N.; Armstrong, A.; et al. Olaparib for Metastatic Breast Cancer in Patients with a Germline BRCA Mutation. N. Engl. J. Med. 2017, 377, 523-533. [CrossRef] [PubMed]

70. Foulkes, W.D.; Smith, I.E.; Reis-Filho, J.S. Triple-Negative Breast Cancer. N. Engl. J. Med. 2010, 363, $1938-1948$. [CrossRef] [PubMed]

71. Nolan, E.; Savas, P.; Policheni, A.N.; Darcy, P.K.; Vaillant, F.; Mintoff, C.P.; Dushyanthen, S.; Mansour, M.; Pang, J.-M.B.; Fox, S.B.; et al. Combined immune checkpoint blockade as a therapeutic strategy for BRCA1 -mutated breast cancer. Sci. Transl. Med. 2017, 9, eaal4922. [CrossRef] [PubMed]

72. Triple-Negative Breast Cancer Responds to New Dual-Target Therapy. Available online: https://www. medicalnewstoday.com/articles/324107\#Triple-negative-breast-cancer (accessed on 31 May 2020).

73. Triple-Negative Breast Cancer: Overview, Treatment, and More. Available online: https://www.breastcancer. org/symptoms/diagnosis/trip_neg (accessed on 31 May 2020).

74. Mouw, K.W.; Goldberg, M.S.; Konstantinopoulos, P.A.; D'Andrea, A.D. DNA damage and repair biomarkers of immunotherapy response. Cancer Discov. 2017, 7, 675-693. [CrossRef] [PubMed]

75. Vinayak, S.; Tolaney, S.M.; Schwartzberg, L.S.; Mita, M.M.; McCann, G.A.-L.; Tan, A.R.; Wahner Hendrickson, A.E.; Forero-Torres, A.; Anders, C.K.; Wulf, G.M.; et al. TOPACIO/Keynote-162: Niraparib + pembrolizumab in patients (pts) with metastatic triple-negative breast cancer (TNBC), a phase 2 trial. J. Clin. Oncol. 2018, 36, 1011. [CrossRef]

76. Galluzzi, L.; Buqué, A.; Kepp, O.; Zitvogel, L.; Kroemer, G. Immunogenic cell death in cancer and infectious disease. Nat. Rev. Immunol. 2017, 17, 97-111. [CrossRef] [PubMed]

77. Demaria, S.; Volm, M.D.; Shapiro, R.L.; Yee, H.T.; Oratz, R.; Formenti, S.C.; Muggia, F.; Symmans, W.F. Development of tumor-infiltrating lymphocytes in breast cancer after neoadjuvant paclitaxel chemotherapy. Clin. Cancer Res. 2001, 7, 3025-3030.

78. Li, J.Y.; Duan, X.F.; Wang, L.P.; Xu, Y.J.; Huang, L.; Zhang, T.F.; Liu, J.Y.; Li, F.; Zhang, Z.; Yue, D.L.; et al. Selective depletion of regulatory $\mathrm{t}$ cell subsets by docetaxel treatment in patients with nonsmall cell lung cancer. J. Immunol. Res. 2014, 2014, 286170. [CrossRef]

79. Roselli, M.; Cereda, V.; di Bari, M.G.; Formica, V.; Spila, A.; Jochems, C.; Farsaci, B.; Donahue, R.; Gulley, J.L.; Schlom, J.; et al. Effects of conventional therapeutic interventions on the number and function of regulatory T cells. Oncoimmunology 2013, 2, e27025. [CrossRef]

80. Kodumudi, K.N.; Woan, K.; Gilvary, D.L.; Sahakian, E.; Wei, S.; Djeu, J.Y. A novel chemoimmunomodulating property of docetaxel: Suppression of myeloid-derived suppressor cells in tumor bearers. Clin. Cancer Res. 2010, 16, 4583-4594. [CrossRef]

81. Ghiringhelli, F.; Menard, C.; Puig, P.E.; Ladoire, S.; Roux, S.; Martin, F.; Solary, E.; Le Cesne, A.; Zitvogel, L.; Chauffert, B. Metronomic cyclophosphamide regimen selectively depletes CD4+CD25+ regulatory T cells and restores $\mathrm{T}$ and NK effector functions in end stage cancer patients. Cancer Immunol. Immunother. 2007, 56, 641-648. [CrossRef] [PubMed] 
82. Kwa, M.; Li, X.; Novik, Y.; Oratz, R.; Jhaveri, K.; Wu, J.; Gu, P.; Meyers, M.; Muggia, F.; Speyer, J.; et al. Serial immunological parameters in a phase II trial of exemestane and low-dose oral cyclophosphamide in advanced hormone receptor-positive breast cancer. Breast Cancer Res. Treat. 2018, 168, 57-67. [CrossRef] [PubMed]

83. Vincent, J.; Mignot, G.; Chalmin, F.; Ladoire, S.; Bruchard, M.; Chevriaux, A.; Martin, F.; Apetoh, L.; Rebe, C.; Ghiringhelli, F. 5-Fluorouracil Selectively Kills Tumor-Associated Myeloid-Derived Suppressor Cells Resulting in Enhanced T Cell-Dependent Antitumor Immunity. Cancer Res. 2010, 70, 3052-3061. [CrossRef] [PubMed]

84. Homma, Y.; Taniguchi, K.; Nakazawa, M.; Matsuyama, R.; Mori, R.; Takeda, K.; Ichikawa, Y.; Tanaka, K.; Endo, I. Changes in the immune cell population and cell proliferation in peripheral blood after gemcitabine-based chemotherapy for pancreatic cancer. Clin. Transl. Oncol. 2014, 16, 330-335. [CrossRef]

85. Huang, X.; Cui, S.; Shu, Y. Cisplatin selectively downregulated the frequency and immunoinhibitory function of myeloid-derived suppressor cells in a murine B16 melanoma model. Immunol. Res. 2016, 64, 160-170. [CrossRef]

86. Nio, Y.; Hirahara, N.; Minari, Y.; Iguchi, C.; Yamasawa, K.; Toga, T.; Tamura, K. Induction of tumor-specific antitumor immunity after chemotherapy with cisplatin in mice bearing MOPC-104E plasmacytoma by modulation of MHC expression on tumor surface. Anticancer Res. 2000, 20, 3293-3299.

87. Jackaman, C.; Majewski, D.; Fox, S.A.; Nowak, A.K.; Nelson, D.J. Chemotherapy broadens the range of tumor antigens seen by cytotoxic CD8+ T cells in vivo. Cancer Immunol. Immunother. 2012, 61, 2343-2356. [CrossRef]

88. Ray Chaudhuri, A.; Nussenzweig, A. The multifaceted roles of PARP1 in DNA repair and chromatin remodelling. Nat. Rev. Mol. Cell Biol. 2017, 18, 610-621. [CrossRef]

89. Litton, J.K.; Rugo, H.S.; Ettl, J.; Hurvitz, S.A.; Gonçalves, A.; Lee, K.-H.; Fehrenbacher, L.; Yerushalmi, R.; Mina, L.A.; Martin, M.; et al. Talazoparib in Patients with Advanced Breast Cancer and a Germline BRCA Mutation. N. Engl. J. Med. 2018, 379, 753-763. [CrossRef]

90. Timms, K.M.; Abkevich, V.; Hughes, E.; Neff, C.; Reid, J.; Morris, B.; Kalva, S.; Potter, J.; Tran, T.V.; Chen, J.; et al. Association of BRCA1/2 defects with genomic scores predictive of DNA damage repair deficiency among breast cancer subtypes. Breast Cancer Res. 2014, 16, 475. [CrossRef]

91. Miles, D.W.; Chan, A.; Dirix, L.Y.; Cortés, J.; Pivot, X.; Tomczak, P.; Delozier, T.; Sohn, J.H.; Provencher, L.; Puglisi, F; et al. Phase III study of bevacizumab plus docetaxel compared with placebo plus docetaxel for the first-line treatment of human epidermal growth factor receptor 2-negative metastatic breast cancer. J. Clin. Oncol. 2010, 28, 3239-3247. [CrossRef] [PubMed]

92. Nanda, R.; Chow, L.Q.M.; Dees, E.C.; Berger, R.; Gupta, S.; Geva, R.; Pusztai, L.; Pathiraja, K.; Aktan, G.; Cheng, J.D.; et al. Pembrolizumab in Patients With Advanced Triple-Negative Breast Cancer: Phase $\mathrm{Ib}$ KEYNOTE-012 Study. J. Clin. Oncol. 2016, 34, 2460. [CrossRef] [PubMed]

93. Motta, L.L.; Ledaki, I.; Purshouse, K.; Haider, S.; De Bastiani, M.A.; Baban, D.; Morotti, M.; Steers, G.; Wig, S.; Bridges, E.; et al. The BET inhibitor JQ1 selectively impairs tumour response to hypoxia and downregulates CA9 and angiogenesis in triple negative breast cancer. Oncogene 2017, 36, 122-132. [CrossRef] [PubMed]

94. Wu, X.; Gu, Z.; Chen, Y.; Chen, B.; Chen, W.; Weng, L.; Liu, X. Application of PD-1 Blockade in Cancer Immunotherapy. Comput. Struct. Biotechnol. J. 2019, 17, 661-674. [CrossRef]

95. FDA Approves Atezolizumab for PD-L1 Positive Unresectable Locally Advanced or Metastatic Triple-Negative Breast Cancer|FDA. Available online: https://www.fda.gov/drugs/drug-approvals-anddatabases/fda-approves-atezolizumab-pd-11-positive-unresectable-locally-advanced-or-metastatic-triplenegative (accessed on 7 October 2019).

96. Rugo, H.S.; Delord, J.P.; Im, S.A.; Ott, P.A.; Piha-Paul, S.A.; Bedard, P.L.; Sachdev, J.; Le Tourneau, C.; van Brummelen, E.M.J.; Varga, A.; et al. Safety and antitumor activity of pembrolizumab in patients with estrogen receptor-positive/human epidermal growth factor receptor 2-negative advanced breast cancer. Clin. Cancer Res. 2018, 24, 2804-2811. [CrossRef] [PubMed]

97. Adams, S.; Schmid, P.; Rugo, H.S.; Winer, E.P.; Loirat, D.; Awada, A.; Cescon, D.W.; Iwata, H.; Campone, M.; Nanda, R.; et al. Phase 2 study of pembrolizumab (pembro) monotherapy for previously treated metastatic triple-negative breast cancer (mTNBC): KEYNOTE-086 cohort A. J. Clin. Oncol. 2017, 35, 1008. [CrossRef] 
98. Rose, A.A.N.; Grosset, A.A.; Dong, Z.; Russo, C.; MacDonald, P.A.; Bertos, N.R.; St-Pierre, Y.; Simantov, R.; Hallett, M.; Park, M.; et al. Glycoprotein nonmetastatic B is an independent prognostic indicator of recurrence and a novel therapeutic target in breast cancer. Clin. Cancer Res. 2010, 16, 2147-2156. [CrossRef]

99. Dirix, L.Y.; Takacs, I.; Jerusalem, G.; Nikolinakos, P.; Arkenau, H.T.; Forero-Torres, A.; Boccia, R.; Lippman, M.E.; Somer, R.; Smakal, M.; et al. Avelumab, an anti-PD-L1 antibody, in patients with locally advanced or metastatic breast cancer: A phase 1b JAVELIN solid tumor study. Breast Cancer Res. Treat. 2018, 167, 671-686. [CrossRef]

100. Wang, X.; Lin, Y. Tumor necrosis factor and cancer, buddies or foes? Acta Pharmacol. Sin. 2008, 29, 1275-1288. [CrossRef]

101. Gonzalez-Suarez, E.; Branstetter, D.; Armstrong, A.; Dinh, H.; Blumberg, H.; Dougall, W.C. RANK Overexpression in Transgenic Mice with Mouse Mammary Tumor Virus Promoter-Controlled RANK Increases Proliferation and Impairs Alveolar Differentiation in the Mammary Epithelia and Disrupts Lumen Formation in Cultured Epithelial Acini. Mol. Cell. Biol. 2007, 27, 1442. [CrossRef]

102. Renema, N.; Navet, B.; Heymann, M.-F.; Lezot, F.; Heymann, D. RANK-RANKL signalling in cancer. Biosci. Rep. 2016, 36, e00366. [CrossRef]

103. Diédhiou, D.; Cuny, T.; Sarr, A.; Norou Diop, S.; Klein, M.; Weryha, G. Efficacy and safety of denosumab for the treatment of osteoporosis: A systematic review. Ann. Endocrinol. (Paris) 2015, 76, 650-657. [CrossRef] [PubMed]

104. Lochter, A. Plasticity of mammary epithelia during normal development and neoplastic progression. Biochem. Cell Biol. 1998, 76, 997-1008. [CrossRef] [PubMed]

105. Li, W.; Zhang, H.; Assaraf, Y.G.; Zhao, K.; Xu, X.; Xie, J.; Yang, D.-H.; Chen, Z.-S. Overcoming ABC transporter-mediated multidrug resistance: Molecular mechanisms and novel therapeutic drug strategies. Drug Resist. Updates 2016, 27, 14-29. [CrossRef]

106. Wang, X.; Zhang, H.; Chen, X. Drug resistance and combating drug resistance in cancer. Cancer Drug Resist. 2019, 2, 141-160. [CrossRef]

107. Shen, F.; Bailey, B.J.; Chu, S.; Bence, A.K.; Xue, X.; Erickson, P.; Safa, A.R.; Beck, W.T.; Erickson, L.C. Dynamic assessment of mitoxantrone resistance and modulation of multidrug resistance by valspodar (PSC833) in multidrug resistance human cancer cells. J. Pharmacol. Exp. Ther. 2009, 330, 423-429. [CrossRef] [PubMed]

108. Aniogo, E.C.; Plackal Adimuriyil George, B.; Abrahamse, H. The role of photodynamic therapy on multidrug resistant breast cancer. Cancer Cell Int. 2019, 19, 91. [CrossRef]

109. Yang, L.; Li, Y.; Bhattacharya, A.; Zhang, Y. A recombinant human protein targeting HER2 overcomes drug resistance in HER2-positive breast cancer. Sci. Transl. Med. 2019, 11, eaav1620. [CrossRef]

110. Vadlapatla, R.K.; Pal, D.; Vadlapudi, A.D.; Mitra, A.K. Ritonavir: A Powerful Boosting Agent for Overcoming Drug Resistance in Cancer Chemotherapy. J. Cancer Sci. Ther. 2014, 6, 446-454. [CrossRef]

111. Allahverdiyev, A.M.; Parlar, E.; Dinparvar, S.; Bagirova, M.; Abamor, E.Ş. Current aspects in treatment of breast cancer based of nanodrug delivery systems and future prospects. Artif. Cells Nanomed. Biotechnol. 2018, 46, S755-S762. [CrossRef]

112. Dadwal, A.; Baldi, A.; Kumar Narang, R. Nanoparticles as carriers for drug delivery in cancer. Artif. Cells Nanomed. Biotechnol. 2018, 46, 295-305. [CrossRef]

113. Zhao, L.; Gu, C.; Gan, Y.; Shao, L.; Chen, H.; Zhu, H. Exosome-mediated siRNA delivery to suppress postoperative breast cancer metastasis. J. Control. Release 2020, 318, 1-15. [CrossRef] [PubMed]

114. Werner, M.E.; Cummings, N.D.; Sethi, M.; Wang, E.C.; Sukumar, R.; Moore, D.T.; Wang, A.Z. Preclinical evaluation of genexol-pm, a nanoparticle formulation of paclitaxel, as a novel radiosensitizer for the treatment of non-small cell lung cancer. Int. J. Radiat. Oncol. Biol. Phys. 2013, 86, 463-468. [CrossRef] [PubMed]

115. Ventola, C.L. Progress in nanomedicine: Approved and investigational nanodrugs. Pharm. Ther. 2017, 42, 742-755.

116. Genexol@PM.-Pharmaceuticals-Product Samyang Biopharmaceuticals. Available online: https://www. samyangbiopharm.com/eng/ProductIntroduce/injection01 (accessed on 31 May 2020).

117. FDA. ABRAXANE®for Injectable Suspension (Paclitaxel Protein-Bound Particles for Injectable Suspension) (Albumin-Bound). Available online: https://www.accessdata.fda.gov/drugsatfda_docs/label/2012/ 021660s031lbl.pdf (accessed on 4 June 2020). 
118. FDA. ABRAXANE @for Injectable Suspension (Paclitaxel Protein-Bound Particles for Injectable Suspension) (Albumin-Bound) (Patient Information Enclosed) ABRAXANE for Injectable Suspension (Paclitaxel Protein-Bound Particles for. Available online: https://www.accessdata.fda.gov/drugsatfda_docs/nda/2012/ 021660Orig1s031.pdf (accessed on 4 June 2020).

119. Doxoves ${ }^{\mathrm{TM}}$ _Liposome Doxorubicin Compared to Doxil ${ }^{\circledR}$. Available online: http://www.liposomeexpert. com/content/FSI\%20files/FSI\%20products/Doxoves\%20-\%20Liposome\%20Doxorubicin\%20Compared\% 20to\%20Doxil.pdf (accessed on 4 June 2020).

120. FDA. DOXIL ${ }^{\circledR}$ (Doxorubicin $\mathrm{HCl}$ Liposome Injection) for Intravenous Infusion. Available online: https: //www.accessdata.fda.gov/drugsatfda_docs/label/2007/050718s029lbl.pdf (accessed on 4 June 2020).

121. FDA. DEPOCYT (Cytarabine Liposome Injection). Available online: https://www.accessdata.fda.gov/ drugsatfda_docs/label/2014/021041s031lbl.pdf (accessed on 4 June 2020).

122. DEPOCYT-Cytarabine Injection, Lipid Complex. Available online: https://www.accessdata.fda.gov/ drugsatfda_docs/label/2011/021041s023lbl.pdf (accessed on 4 June 2020).

123. Panel Recommends FDA Approval of DepoCyt. Available online: https:/www.cancernetwork.com/articles/ panel-recommends-fda-approval-depocyt (accessed on 4 June 2020).

124. Lipodox-FDA. Prescribing Information, Side Effects and Uses. Available online: https://www.drugs.com/pro/ lipodox.html (accessed on 31 May 2020).

125. Yu, D.S.; Yan, H.Y.; Wu, C.L.; Hung, S.H. Comparison of therapeutic efficacy of lipo-doxorubicin and doxorubicin in treating bladder cancer. Urol. Sci. 2017, 28, 200-205. [CrossRef]

126. DaunoXome-FDA. Prescribing Information, Side Effects and Uses. Available online: https://www.drugs. com/pro/daunoxome.html (accessed on 31 May 2020).

127. DaunoXome ${ }^{\circledR}$ (Daunorubicin Citrate Liposome Injection). Available online: https://hemonc.org/w/images/d/ d2/Daunorubicinliposomal.pdf (accessed on 4 June 2020).

128. Guo, C.; Chen, Y.; Gao, W.; Chang, A.; Ye, Y.; Shen, W.; Luo, Y.; Yang, S.; Sun, P.; Xiang, R.; et al. Liposomal nanoparticles carrying anti-IL6R antibody to the tumour microenvironment inhibit metastasis in two molecular subtypes of breast cancer mouse models. Theranostics 2017, 7, 775-788. [CrossRef]

129. Salkho, N.M.; Paul, V.; Kawak, P.; Vitor, R.F.; Martins, A.M.; Al Sayah, M.; Husseini, G.A. Ultrasonically controlled estrone-modified liposomes for estrogen-positive breast cancer therapy. Artif. Cells Nanomed. Biotechnol. 2018, 46, 462-472. [CrossRef]

130. Zhang, N.; Zhang, J.; Wang, P.; Liu, X.; Huo, P.; Xu, Y.; Chen, W.; Xu, H.; Tian, Q. Investigation of an antitumor drug-delivery system based on anti-HER2 antibody-conjugated BSA nanoparticles. Anticancer Drugs 2018, 29, 307-322. [CrossRef]

131. Viravaidya-Pasuwat, K.; Naruphontjirakul, P. Development of anti-her2-targeted doxorubicin-core-shell chitosan nanoparticles for the treatment of human breast cancer. Int. J. Nanomed. 2019, 14, 4105-4121.

132. Kim, B.; Shin, J.; Wu, J.; Omstead, D.T.; Kiziltepe, T.; Littlepage, L.E.; Bilgicer, B. Engineering peptide-targeted liposomal nanoparticles optimized for improved selectivity for HER2-positive breast cancer cells to achieve enhanced in vivo efficacy. J. Control. Release 2020, 322, 530-541. [CrossRef]

133. Cristofolini, T.; Dalmina, M.; Sierra, J.A.; Silva, A.H.; Pasa, A.A.; Pittella, F.; Creczynski-Pasa, T.B. Multifunctional hybrid nanoparticles as magnetic delivery systems for siRNA targeting the HER2 gene in breast cancer cells. Mater. Sci. Eng. C 2020, 109, 110555. [CrossRef] [PubMed]

134. Rong, L.; Zhou, S.; Liu, X.; Li, A.; Jing, T.; Liu, X.; Zhang, Y.; Cai, S.; Tang, X. Trastuzumab-modified DM1-loaded nanoparticles for HER2 + breast cancer treatment: An in vitro and in vivo study. Artif. Cells Nanomed. Biotechnol. 2018, 46, 1708-1718. [CrossRef] [PubMed]

135. Cerqueira, B.B.S.; Lasham, A.; Shelling, A.N.; Al-Kassas, R. Development of biodegradable PLGA nanoparticles surface engineered with hyaluronic acid for targeted delivery of paclitaxel to triple negative breast cancer cells. Mater. Sci. Eng. C 2017, 76, 593-600. [CrossRef]

136. Siddhartha, V.T.; Pindiprolu, S.K.S.S.; Chintamaneni, P.K.; Tummala, S.; Nandha Kumar, S. RAGE receptor targeted bioconjuguate lipid nanoparticles of diallyl disulfide for improved apoptotic activity in triple negative breast cancer: In vitro studies. Artif. Cells Nanomed. Biotechnol. 2018, 46, 387-397. [CrossRef] [PubMed] 
137. Kamalabadi-Farahani, M.; Vasei, M.; Ahmadbeigi, N.; Ebrahimi-Barough, S.; Soleimani, M.; Roozafzoon, R. Anti-tumour effects of TRAIL-expressing human placental derived mesenchymal stem cells with curcumin-loaded chitosan nanoparticles in a mice model of triple negative breast cancer. Artif. Cells Nanomed. Biotechnol. 2018, 46, S1011-S1021. [CrossRef] [PubMed]

138. Kavithaa, K.; Paulpandi, M.; Padma, P.R.; Sumathi, S. Induction of intrinsic apoptotic pathway and cell cycle arrest: Via baicalein loaded iron oxide nanoparticles as a competent nano-mediated system for triple negative breast cancer therapy. RSC Adv. 2016, 6, 64531-64543. [CrossRef]

139. Bhattacharya, S.; Ghosh, A.; Maiti, S.; Ahir, M.; Debnath, G.H.; Gupta, P.; Bhattacharjee, M.; Ghosh, S.; Chattopadhyay, S.; Mukherjee, P.; et al. Delivery of thymoquinone through hyaluronic acid-decorated mixed Pluronic $囚$ nanoparticles to attenuate angiogenesis and metastasis of triple-negative breast cancer. J. Control. Release 2020, 322, 357-374. [CrossRef]

140. Ngamcherdtrakul, W.; Morry, J.; Gu, S.; Castro, D.J.; Goodyear, S.M.; Sangvanich, T.; Reda, M.M.; Lee, R.; Mihelic, S.A.; Beckman, B.L.; et al. Cationic Polymer Modified Mesoporous Silica Nanoparticles for Targeted siRNA Delivery to HER2 + Breast Cancer. Adv. Funct. Mater. 2015, 25, 2646-2659. [CrossRef]

141. Shavi, G.V.; Nayak, U.Y.; Maliyakkal, N.; Deshpande, P.B.; Raghavendra, R.; Kumar, A.R.; Reddya, M.S.; Udupa, N.; Shrawan, B. Nanomedicine of anastrozole for breast cancer: Physicochemical evaluation, in vitro cytotoxicity on BT-549 and MCF-7 cell lines and preclinical study on rat model. Life Sci. 2015, 141, 143-155. [CrossRef]

142. DeVeaux, S.D.; Gomillion, C.T. Assessing the Potential of Chitosan/Polylactide Nanoparticles for Delivery of Therapeutics for Triple-Negative Breast Cancer Treatment. Regen. Eng. Transl. Med. 2019, 5, 61-73. [CrossRef]

143. Jin, G.; He, R.; Liu, Q.; Dong, Y.; Lin, M.; Li, W.; Xu, F. Theranostics of Triple-Negative Breast Cancer Based on Conjugated Polymer Nanoparticles. ACS Appl. Mater. Interfaces 2018, 10, 10634-10646. [CrossRef] [PubMed]

144. Li, N.; Zhang, P.; Huang, C.; Song, Y.; Garg, S.; Luan, Y. Co-delivery of doxorubicin hydrochloride and verapamil hydrochloride by $\mathrm{pH}$-sensitive polymersomes for the reversal of multidrug resistance. RSC Adv. 2015, 5, 77986-77995. [CrossRef]

145. Yao, Y.; Saw, P.E.; Nie, Y.; Wong, P.P.; Jiang, L.; Ye, X.; Chen, J.; Ding, T.; Xu, L.; Yao, H.; et al. Multifunctional sharp $\mathrm{pH}$-responsive nanoparticles for targeted drug delivery and effective breast cancer therapy. J. Mater. Chem. B 2019, 7, 576-585. [CrossRef] [PubMed]

146. Yin, T.; Wang, L.; Yin, L.; Zhou, J.; Huo, M. Biomaterials Co-delivery of hydrophobic paclitaxel and hydrophilic AURKA speci fi c siRNA by redox-sensitive micelles for effective treatment of breast cancer. Biomaterials 2015, 61, 10-25. [CrossRef]

147. Nima, Z.A.; Watanabe, F.; Jamshidi-Parsian, A.; Sarimollaoglu, M.; Nedosekin, D.A.; Han, M.; Watts, J.A.; Biris, A.S.; Zharov, V.P.; Galanzha, E.I. Bioinspired magnetic nanoparticles as multimodal photoacoustic, photothermal and photomechanical contrast agents. Sci. Rep. 2019, 9, 887. [CrossRef]

148. Xie, X.; Chen, Y.; Chen, Z.; Feng, Y.; Wang, J.; Li, T.; Li, S.; Qin, X.; Wu, C.; Zheng, C.; et al. Polymeric Hybrid Nanomicelles for Cancer Theranostics: An Efficient and Precise Anticancer Strategy for the Codelivery of Doxorubicin/miR-34a and Magnetic Resonance Imaging. ACS Appl. Mater. Interfaces 2019, 11, 43865-43878. [CrossRef]

149. Meng, J.; Guo, F.; Xu, H.; Liang, W.; Wang, C.; Yang, X. Combination Therapy using Co-encapsulated Resveratrol and Paclitaxel in Liposomes for Drug Resistance Reversal in Breast Cancer Cells in vivo. Sci. Rep. 2016, 6, 22390. [CrossRef]

150. Shavi, G.V.; Reddy, M.S.; Raghavendra, R.; Nayak, U.Y.; Kumar, A.R.; Deshpande, P.B.; Udupa, N.; Behl, G.; Dave, V.; Kushwaha, K. PEGylated liposomes of anastrozole for long-term treatment of breast cancer: In vitro and in vivo evaluation. J. Liposome Res. 2016, 26, 28-46. [CrossRef]

151. Piccolo, M.; Misso, G.; Ferraro, M.G.; Riccardi, C.; Capuozzo, A.; Zarone, M.R.; Maione, F.; Trifuoggi, M.; Stiuso, P.; D'Errico, G.; et al. Exploring cellular uptake, accumulation and mechanism of action of a cationic Ru-based nanosystem in human preclinical models of breast cancer. Sci. Rep. 2019, 9, 7006. [CrossRef]

152. Kamoun, W.S.; Kirpotin, D.B.; Huang, Z.R.; Tipparaju, S.K.; Noble, C.O.; Hayes, M.E.; Luus, L.; Koshkaryev, A.; Kim, J.; Olivier, K.; et al. Antitumour activity and tolerability of an EphA2-targeted nanotherapeutic in multiple mouse models. Nat. Biomed. Eng. 2019, 3, 264-280. [CrossRef] 
153. Yue, W.; Chen, L.; Yu, L.; Zhou, B.; Yin, H.; Ren, W.; Liu, C.; Guo, L.; Zhang, Y.; Sun, L.; et al. Checkpoint blockade and nanosonosensitizer-augmented noninvasive sonodynamic therapy combination reduces tumour growth and metastases in mice. Nat. Commun. 2019, 10, 2025. [CrossRef] [PubMed]

154. Yassemi, A.; Kashanian, S.; Zhaleh, H. Folic acid receptor-targeted solid lipid nanoparticles to enhance cytotoxicity of letrozole through induction of caspase-3 dependent-apoptosis for breast cancer treatment. Pharm. Dev. Technol. 2020, 25, 397-407. [CrossRef] [PubMed]

155. Abd-Ellatef, G.E.F.; Gazzano, E.; Chirio, D.; Hamed, A.R.; Belisario, D.C.; Zuddas, C.; Peira, E.; Rolando, B.; Kopecka, J.; Marie, M.A.S.; et al. Curcumin-loaded solid lipid nanoparticles bypass p-glycoprotein mediated doxorubicin resistance in triple negative breast cancer cells. Pharmaceutics 2020, 12, 96. [CrossRef] [PubMed]

156. Li, X.; Jia, X.; Niu, H. Nanostructured lipid carriers co-delivering lapachone and doxorubicin for overcoming multidrug resistance in breast cancer therapy. Int. J. Nanomed. 2018, 13, 4107-4119. [CrossRef]

157. Poonia, N.; Kaur Narang, J.; Lather, V.; Beg, S.; Sharma, T.; Singh, B.; Pandita, D. Resveratrol loaded functionalized nanostructured lipid carriers for breast cancer targeting: Systematic development, characterization and pharmacokinetic evaluation. Colloids Surfaces B Biointerfaces 2019, 181, 756-766. [CrossRef]

158. Zhang, Q.; Zhao, J.; Hu, H.; Yan, Y.; Hu, X.; Zhou, K.; Xiao, S.; Zhang, Y.; Feng, N. Construction and in vitro and in vivo evaluation of folic acid-modified nanostructured lipid carriers loaded with paclitaxel and chlorin e6. Int. J. Pharm. 2019, 569, 118595. [CrossRef]

159. Liang, T.; Yao, Z.; Ding, J.; Min, Q.; Jiang, L.; Zhu, J.J. Cascaded Aptamers-Governed Multistage Drug-Delivery System Based on Biodegradable Envelope-Type Nanovehicle for Targeted Therapy of HER2-Overexpressing Breast Cancer. ACS Appl. Mater. Interfaces 2018, 10, 34050-34059. [CrossRef]

160. Ray, S.; Li, Z.; Hsu, C.H.; Hwang, L.P.; Lin, Y.C.; Chou, P.T.; Lin, Y.Y. Dendrimer-and copolymer-based nanoparticles for magnetic resonance cancer theranostics. Theranostics 2018, 8, 6322-6349. [CrossRef]

161. Nosrati, H.; Adibtabar, M.; Sharafi, A.; Danafar, H. PAMAM-modified citric acid-coated magnetic nanoparticles as $\mathrm{pH}$ sensitive biocompatible carrier against human breast cancer cells. Drug Dev. Ind. Pharm. 2018, 44, 1377-1384. [CrossRef]

162. Kulhari, H.; Pooja, D.; Shrivastava, S.; Kuncha, M.; Naidu, V.G.M.; Bansal, V.; Sistla, R.; Adams, D.J. Trastuzumab-grafted PAMAM dendrimers for the selective delivery of anticancer drugs to HER2-positive breast cancer. Sci. Rep. 2016, 6, 23179. [CrossRef]

163. Liu, C.; Gao, H.; Zhao, Z.; Rostami, I.; Wang, C.; Zhu, L.; Yang, Y. Improved tumor targeting and penetration by a dual-functional poly(amidoamine) dendrimer for the therapy of triple-negative breast cancer. J. Mater. Chem. B 2019, 7, 3724-3736. [CrossRef]

164. Torres-Pérez, S.A.; del Ramos-Godínez, M.P.; Ramón-Gallegos, E. Effect of methotrexate conjugated PAMAM dendrimers on the viability of breast cancer cells. AIP Conf. Proc. 2019, 2090, 050014.

165. Li, N.; Guo, C.; Duan, Z.; Yu, L.; Luo, K.; Lu, J.; Gu, Z. A stimuli-responsive Janus peptide dendron-drug conjugate as a safe and nanoscale drug delivery vehicle for breast cancer therapy. J. Mater. Chem. B 2016, 4, 3760-3769. [CrossRef]

166. Wang, Y.M.; Wu, Z.; Liu, S.J.; Chu, X. Structure-Switching Aptamer Triggering Hybridization Chain Reaction on the Cell Surface for Activatable Theranostics. Anal. Chem. 2015, 87, 6470-6474. [CrossRef]

167. Hasanzadeh, M.; Razmi, N.; Mokhtarzadeh, A.; Shadjou, N.; Mahboob, S. Aptamer based assay of plated-derived grow factor in unprocessed human plasma sample and MCF-7 breast cancer cell lysates using gold nanoparticle supported $\alpha$-cyclodextrin. Int. J. Biol. Macromol. 2018, 108, 69-80. [CrossRef] [PubMed]

168. Li, X.; Wu, X.; Yang, H.; Li, L.; Ye, Z.; Rao, Y. A nuclear targeted Dox-aptamer loaded liposome delivery platform for the circumvention of drug resistance in breast cancer. Biomed. Pharmacother. 2019, 117, 109072. [CrossRef] [PubMed]

169. Duan, T.; Xu, Z.; Sun, F.; Wang, Y.; Zhang, J.; Luo, C.; Wang, M. HPA aptamer functionalized paclitaxel-loaded PLGA nanoparticles for enhanced anticancer therapy through targeted effects and microenvironment modulation. Biomed. Pharmacother. 2019, 117, 109121. [CrossRef] [PubMed]

170. Gao, F.; Wu, J.; Gao, H.; Hu, X.; Liu, L.; Midgley, A.C.; Liu, Q.; Sun, Z.; Liu, Y.; Ding, D.; et al. Hypoxia-tropic nanozymes as oxygen generators for tumor-favoring theranostics. Biomaterials 2020, 230, 119635. [CrossRef]

171. Siminzar, P.; Omidi, Y.; Golchin, A.; Aghanejad, A.; Barar, J. Targeted delivery of doxorubicin by magnetic mesoporous silica nanoparticles armed with mucin-1 aptamer. J. Drug Target. 2020, 28, 92-101. [CrossRef] 
172. Park, S.; Kim, H.; Lim, S.C.; Lim, K.; Lee, E.S.; Oh, K.T.; Choi, H.G.; Youn, Y.S. Gold nanocluster-loaded hybrid albumin nanoparticles with fluorescence-based optical visualization and photothermal conversion for tumor detection/ablation. J. Control. Release 2019, 304, 7-18. [CrossRef]

173. Choi, G.; Kwon, O.; Oh, Y.; Yun, C.; Choy, J. Inorganic Nanovehicle Targets Tumor in an Orthotopic Breast Cancer Model. Sci. Rep. 2014, 4, 4430. [CrossRef] [PubMed]

174. Xu, W.; Qian, J.; Hou, G.; Wang, Y.; Wang, J.; Sun, T.; Ji, L.; Suo, A.; Yao, Y. A dual-targeted hyaluronic acid-gold nanorod platform with triple-stimuli responsiveness for photodynamic/photothermal therapy of breast cancer. Acta Biomater. 2019, 83, 400-413. [CrossRef] [PubMed]

175. Li, B.; Xu, Q.; Li, X.; Zhang, P.; Zhao, X.; Wang, Y. Redox-responsive hyaluronic acid nanogels for hyperthermiaassisted chemotherapy to overcome multidrug resistance. Carbohydr. Polym. 2019, 203, 378-385. [CrossRef] [PubMed]

176. Crawford, L.J.; Walker, B.; Irvine, A.E. Proteasome inhibitors in cancer therapy. J. Cell Commun. Signal. 2011, 5, 101-110. [CrossRef]

177. Gu, Y.; Bouwman, P.; Greco, D.; Saarela, J.; Yadav, B.; Jonkers, J.; Kuznetsov, S.G. Suppression of BRCA1 sensitizes cells to proteasome inhibitors. Cell Death Dis. 2014, 5, e1580. [CrossRef]

178. Gu, S.; Hu, Z.; Ngamcherdtrakul, W.; Castro, D.J.; Morry, J.; Reda, M.M.; Gray, J.W.; Yantasee, W. Therapeutic siRNA for drug-resistant HER2-positive breast cancer. Oncotarget 2016, 7, 14727-14741. [CrossRef]

179. Parmar, M.B.; Bahadur K.C., R.; Löbenberg, R.; Uludağ, H. Additive Polyplexes to Undertake siRNA Therapy against CDC20 and Survivin in Breast Cancer Cells. Biomacromolecules 2018, 19, 4193-4206. [CrossRef]

180. Gao, Y.; Zhang, L.; Liu, Y.; Sun, S.; Yin, Z.; Zhang, L.; Li, A.; Lu, G.; Wu, A.; Zeng, L. Ce6/Mn2+-chelated polydopamine@black-TiO2 nanoprobes for enhanced synergistic phototherapy and magnetic resonance imaging in $4 \mathrm{~T} 1$ breast cancer. Nanoscale 2020, 12, 1801-1810. [CrossRef]

181. Li, L.; Lu, Y.; Jiang, C.; Zhu, Y.; Yang, X.; Hu, X.; Lin, Z. Actively Targeted Deep Tissue Imaging and Photothermal-Chemo Therapy of Breast Cancer by Antibody-Functionalized Drug-Loaded X-Ray-Responsive Bismuth Sulfide @ Mesoporous Silica Core-Shell Nanoparticles. Adv. Funct. Mater. 2018, 28, 1704623. [CrossRef]

182. Sayed, A.; Halwani, R. Specific targeting and noninvasive imaging of breast cancer stem cells using single-walled carbon nanotubes as novel multimodality nanoprobes. Nanomedicine 2016, 11, 31-46.

183. Yu, S.; Zhang, Y.; Chen, L.; Li, Q.; Du, J.; Gao, Y.; Zhang, L.; Yang, Y. Antitumor effects of carbon nanotube-drug complex against human breast cancer cells. Exp. Ther. Med. 2018, 16, 1103-1110. [CrossRef] [PubMed]

184. Singh, S.; Mehra, N.K.; Jain, N.K. Development and Characterization of the Paclitaxel loaded Riboflavin and Thiamine Conjugated Carbon Nanotubes for Cancer Treatment. Pharm. Res. 2016, 33, 1769-1781. [CrossRef] [PubMed]

185. Morton, J.G.; Day, E.S.; Halas, N.J.; West, J.L. Nanoshells for photothermal cancer therapy. Methods Mol. Biol. 2010, 624, 101-117. [PubMed]

186. Ramasamy, T.; Ruttala, H.B.; Sundaramoorthy, P.; Poudel, B.K.; Youn, Y.S.; Ku, S.K.; Choi, H.; Yong, C.S.; Kim, J.O. Multimodal selenium nanoshell-capped Au@mSi 2 nanoplatform for NIR-responsive chemo-photothermal therapy against metastatic breast cancer. NPG Asia Mater. 2018, 10, 197-216. [CrossRef]

187. Nunes, T.; Pons, T.; Hou, X.; Van Do, K.; Caron, B.; Rigal, M.; Di Benedetto, M.; Palpant, B.; Leboeuf, C.; Janin, A.; et al. Pulsed-laser irradiation of multifunctional gold nanoshells to overcome trastuzumab resistance in HER2-overexpressing breast cancer. J. Exp. Clin. Cancer Res. 2019, 38, 306. [CrossRef] [PubMed]

188. Chauhan, D.S.; Reddy, B.P.K.; Mishra, S.K.; Prasad, R.; Dhanka, M.; Vats, M.; Ravichandran, G.; Poojari, D.; Mhatre, O.; De, A.; et al. Comprehensive Evaluation of Degradable and Cost-Effective Plasmonic Nanoshells for Localized Photothermolysis of Cancer Cells. Langmuir 2019, 35, 7805-7815. [CrossRef]

189. Esfandiari, N. Targeting Breast Cancer With Bio-inspired Virus Nanoparticles. Arch. Breast Cancer 2018, 5 , 90-95.

190. Esfandiari, N.; Arzanani, M.K.; Soleimani, M. A new application of plant virus nanoparticles as drug delivery in breast cancer. Tumor Biol. 2016, 37, 1229-1236. [CrossRef]

191. Bruckman, M.A.; Czapar, A.E.; VanMeter, A.; Randolph, L.N.; Steinmetz, N.F. Tobacco mosaic virus-based protein nanoparticles and nanorods for chemotherapy delivery targeting breast cancer. J. Control. Release 2016, 231, 103-113. [CrossRef]

192. AI Reveals New Breast Cancer Types That Respond Differently to Treatment. Available online: https: //www.sciencedaily.com/releases/2019/08/190802131354.htm (accessed on 4 June 2020). 
193. Ho, D.; Wang, P.; Kee, T. Artificial intelligence in nanomedicine. Nanoscale Horiz. 2019, 4, 365-377. [CrossRef]

194. Adir, O.; Poley, M.; Chen, G.; Froim, S.; Krinsky, N.; Shklover, J.; Shainsky-Roitman, J.; Lammers, T.; Schroeder, A. Integrating Artificial Intelligence and Nanotechnology for Precision Cancer Medicine. Adv. Mater. 2020, 32, 1901989. [CrossRef] [PubMed]

195. Marcu, L.G.; Boyd, C.; Bezak, E. Current issues regarding artificial intelligence in cancer and health care. Implications for medical physicists and biomedical engineers. Health Technol. (Berl.) 2019, 9, 375-381. [CrossRef]

196. Crisponi, G.; Nurchi, V.M.; Lachowicz, J.I.; Peana, M.; Medici, S.; Zoroddu, M.A. Toxicity of Nanoparticles: Etiology and Mechanisms. In Antimicrobial Nanoarchitectonics: From Synthesis to Applications; Elsevier Inc.: Amsterdam, The Netherlands, 2017; pp. 511-546. ISBN 9780323527347.

197. Khan, I.; Saeed, K.; Khan, I. Nanoparticles: Properties, applications and toxicities. Arab. J. Chem. 2019, 12, 908-931. [CrossRef]

198. Borghaei, H.; Paz-Ares, L.; Horn, L.; Spigel, D.R.; Steins, M.; Ready, N.E.; Chow, L.Q.; Vokes, E.E.; Felip, E.; Holgado, E.; et al. Nivolumab versus docetaxel in advanced nonsquamous non-small-cell lung cancer. N. Engl. J. Med. 2015, 373, 1627-1639. [CrossRef]

199. Postow, M.A.; Sidlow, R.; Hellmann, M.D. Immune-related adverse events associated with immune checkpoint blockade. N. Engl. J. Med. 2018, 378, 158-168. [CrossRef]

200. Gambichler, T.; Strutzmann, S.; Tannapfel, A.; Susok, L. Paraneoplastic acral vascular syndrome in a patient with metastatic melanoma under immune checkpoint blockade. BMC Cancer 2017, 17, 327. [CrossRef]

201. What Is Gene Therapy?|OncoLink. Available online: https:/www.oncolink.org/cancer-treatment/ immunotherapy/what-is-gene-therapy (accessed on 14 February 2020).

(C) 2020 by the authors. Licensee MDPI, Basel, Switzerland. This article is an open access article distributed under the terms and conditions of the Creative Commons Attribution (CC BY) license (http://creativecommons.org/licenses/by/4.0/). 